Çelik, E. ve Kızılaslan Tunçer, B. (2020). Illkokul 4. sınıf öğrencilerinin anne-babalarının okuma tutumları ile Türkçe dersi akademik başarısı arasındaki ilişki. Ana Dili Eğitimi Dergisi, 8(4), 1094-1114.

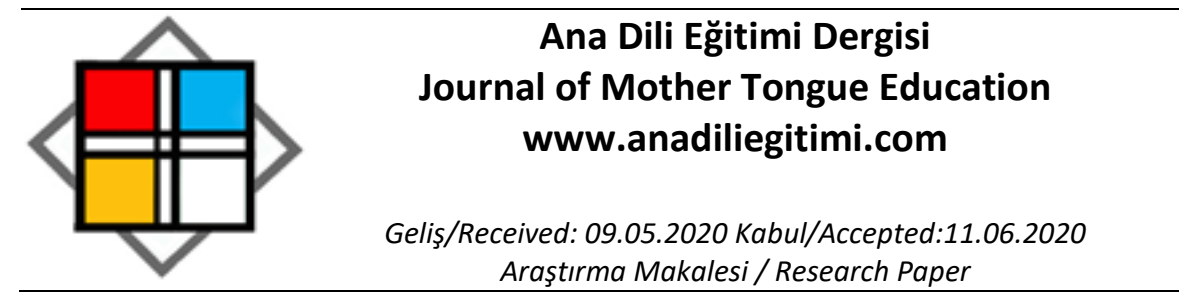

\title{
İlkokul 4. Sınıf Öğrencilerinin Anne-Babalarının Okuma Tutumları ile Türkçe Dersi Akademik Başarısı Arasındaki ílişki
}

\author{
Enise ÇELIK* \\ Berfu KIZILASLAN TUNÇER **
}

\begin{abstract}
Öz
Ilkokul 4. Sınıf öğrencilerinin anne-babalarının okuma tutumları ile Türkçe dersi akademik başarıları arasında bir ilişki olup olmadığı inceleyen bu çalışma ilişkisel tarama modelindedir. Araştırmanın evreni, Çanakkale'nin Merkez ilçesindeki ilkokullarda öğrenim gören 4. Sınıf öğrencileri ve annebabalarından oluşmaktadır. Basit seçkisiz örnekleme yöntemi kullanılarak çalışmaya 203 veli dahil edilmiştir. Veri toplama aracı olarak araştırmacı tarafından geliştirilen "Okumaya Yönelik Tutum Ölçeği”" ile "Kişisel Bilgi Formu" kullanılmıştır. Verilerin analizi için SPSS paket programı kullanılmış, Aritmetik Ortalama, Frekans, Standart Sapma, Yüzde, t Testi, Anova Testi, Pearson Korelasyon Katsayısı Testi ve Kolmogorov Smirnov Testi uygulanmıştır. Sonuçlara göre, anne-babaların kitap okumaya ilişkin tutumunun yüksek düzeyde olduğu, anne-babaların okuma tutumlarının öğrenim durumları, aylık gelirleri, kitap okuma sıklıklarına göre farklılaştığı fakat yaş, meslek ve çocuk sayısına göre farkıllaşmadığı belirlenmiştir. Ayrıca öğrencilerin Türkçe dersi akademik başarılarının yüksek düzeyde olduğu, çocukların kitaplıklarının varlığı ve anne-babaların kitap okuma sıklıklarına göre öğrencilerin Türkçe dersi akademik başarılarında anlamlı bir farklılığın görülmediği belirlenmiştir. Bunun yanı sıra ilkokul öğrencilerinin Türkçe dersi akademik başarıları ile anne babalarının okuma tutumları arasında düşük düzeyde anlamlı ve pozitif bir ilişkiye rastlanmıştır.

Anahtar Kelimeler: Türkçe Öğretimi, Akademik Başarı, Okuma Tutumu, Anne-baba, Okuma Alışkanlığı

\section{Relationship between the 4th Grade Students' Academic Achievement in Turkish Course and Their Parents' Reading Attitudes}

\begin{abstract}
This descriptive study is a correlational survey, which investigates whether there is a relationship between reading attitudes of parents of the $4^{\text {th }}$ grade elementary students and their academic achievement in Turkish class. Participants of the study consists of the $4^{\text {th }}$ grade students at elementary schools in Çanakkale and their parents. 203 parents were included in the study by adopting simple random sampling method. "Attitude Scale for Reading" and "Personal Information Form", developed by the researchers, were employed as data collection tools. SPSS, a statistical software program, was used for data analysis. Indepent samples t-Test, One-way ANOVA Test, Pearson's Correlation Coefficient Test, and Kolmogorov-Smirnov Test were employed for the purpose of the study. The calculated means, frequencies, standard deviations, and percentages were considered in the analyses. Findings revealed that the parents held positive attitudes toward reading books and that their educational status, monthly income, and reading attitudes differed by frequency of reading but not by age, profession, and number of children. In addition, the students were determined to be highly successful in Turkish class course. No significant difference was observed between participants' academic achievement levels in Turkish course in terms of
\end{abstract}

\footnotetext{
* Öğretmen, Bahçeşehir Koleji, Çanakkale, enisealtunkaynak@gmail.com, ORCID: 0000-0001-9156-8627

** Dr. Öğr. Üyesi, Çanakkale Onsekiz Mart Üniversitesi, Eğitim Fakültesi, Temel Eğitim Bölümü, Çanakkale, berfutuncer@gmail.com, ORCID: 0000-0001-5184-4869
} 
their personal home library and the frequency of their parents' book reading. Besides, a weak significant positive relationship was found between the elementary students' academic achievement in the Turkish course and their parents' reading attitudes.

Keywords: Turkish Teaching, Academic Achievement, Reading Attitude, Parents, Reading Habit

\section{Giriş}

Sosyal bir varlık olan insan için önemli bir ihtiyaç olan iletişimin temel unsuru dildir. Dilin bu denli öneme sahip olması, insanları dil öğrenme ve öğretme konusunu araştırmaya yönlendirmiştir. Bir iletişim ve bildirim aracı olan dil, aynı zamanda kültürün gelecek nesillere aktarılmasında da önemli bir paya sahiptir. İnsan için temel olan ve ilk öğrendiği dil ana dildir (Akyol ve Şahin, 2019 :213). Dolayısıyla ana dilimizi etkili bir şekilde kullanmak, duygu ve düşüncelerimizi çevremiz ile paylaşmak, sözlü ve yazılı bir biçimde ifade edebilmek için de dil eğitimi almaya gereksinim duyarız.

Dilin çeşitli alanları öğrenme sürecinde yer almaktadır. Bu alanlar dinleme, konuşma, okuma, yazma, görsel okuma ve görsel sunu olarak sıralanmaktadır. Öğrenme sürecinde en çok ihtiyaç duyulan okuma becerileridir. Birey okuyarak birçok bilgiye kısa sürede ulaşmakta, aktif öğrenme gerçekleştirmekte ve kendini devamlı geliştirerek günlük hayatında başarılı olmaktadır. Okuma, bireyin dil, zihinsel, duygusal, sosyal, kültürel yönlerden gelişimine katkılar sunan bir alandır. Ayrıca okuma, iletişim kurma, çağdaş topluma adapte olma, kararlarını bilinçli bir şekilde verme ve öğrenmeyi sürdürme gibi üst düzey becerileri de geliştirmektedir. Bu sebeple eğitim sürecinde öğrencilerin okuma becerilerini geliştirmeye öncelik verilmektedir (Güneş, 2017). Diğer dil becerileriyle yakın ilişki içerisinde olan okuma ve dinleme ile insan dış dünyayı algılayıp anlamlandırır; konuşma ve yazma becerisiyle ise duygu, düşünce, hayal ve izlenimlerini karşısındakilere aktarır. Bu bakımdan dinleme ve okuma anlama, konuşma ve yazma anlatma becerisidir (Arıcı ve Taşkın, 2019). Bireyin dil becerilerini kazanabilmesi ise Türkçe derslerinde verilen kazanımlar ile ilgilidir. Bu anlamda süreç, bireylerin doğumunun ardından dinleme ve konuşma becerisi kazanması, öğrenciliğin ilk anlarından itibaren ise okuma ve yazma becerisi kazanması ve bu becerileri hayat boyu kullanması ile devam etmektedir.

Okuma, yazılı mesajları duyu organları aracılı̆ıyla algılayarak kavrama, anlamlandırma, yorumlama, düşünce yürütme ve sonuca ulaşma aşamalarını barındıran bütünsel bir süreçtir. Bu anlamda okuma, duyu organlarının iş birliğiyle yapılan bir faaliyettir (Odabaş, Odabaş ve Polat, 2008: 433). Aksaçlıoğlu ve Yılmaz (2007:4)'a göre en etkin ve en eski öğrenme şekli olan okuma; zihinsel, bireysel ve yaratıcı bir süreçtir. Okuma aynı zamanda boş vakitleri doldurmak, ekonomik, kültürel ve teknolojik gelişimleri takip etmek, yeni bilgiler edinmek için yapılan bir faaliyet şeklinde de tanımlanabilir. Okuma eylemi öğrenmenin temelini oluşturduğu gibi, insanın gelişimine de sayısız yarar sağlar. Kişisel anlamda okumak hem beynimizi hem de ruhumuzu doyuran, duyuşsal ve bilişsel etkinlikler bütünüdür. Okumak, sağlıklı beyin gelişiminin ve sağlıklı düşünebilmenin en doğru yoludur. Okumayan bireylerin kelime hazinesi daraldığından dolayı düşünebilme becerileri de sınırlanmaktadır (Inan, 2005).

Okuma eylemi tüm derslere temel teşkil etmektedir. Çünkü okuma, bir öğrenme yoludur ve öğrenilen bilgilerin kişinin hafızasına transferi konusunda önemli bir araçtır. Okuma ve anlamayı tam olarak gerçekleştiremeyen bir öğrenciden akademik bir başarı beklenemez (Çelenk, 2005: 142). İlköğretim döneminde okuma alışkanlığı kazanamayan öğrenciler daha sonraki süreçte de başarısız olabilmektedirler (Akyol, 2009:2).

Okuma alışkanlığına etki eden birçok etmen vardır. Bu alışkanlığın kazanılmasını ve geliştirilmesini etkileyen etmenlerin başında çevre, aile, öğretmen ve okul gelmektedir (Özbay, 2005; Özbay, 2006; Yılmaz 2004). Yalnızca fiziksel ve zihinsel beceriler ile okuma alışkanlığı kazanılamaz, bunun yanı sıra okuma becerisi ile ilgili eğitim de alınmış olması gerekmektedir. Bu eğitim ailede başlamaktadır. Çocukların okuma eğitimini kazanabilmeleri için ihtiyaçları olan hazırbulunuşluğu kazandırmak, onlara okuma ortamını sağlama yoluyla oluşur (Elbir ve Bağcı, 2013).

Çoğu sosyolojik yaşantıda olduğu gibi okuma eyleminde de çevrenin büyük bir önemi vardır. Bir çocuğun çevresindeki okumaya yönelik olan olumlu uyarıcılarla çocuğun okuma alışkanlığı kazanması arasında doğru orantı vardır. Eğer çocuğun bulunduğu ortamda okuma kültürü oluşmamış 
ve okumaya karşı olumlu bir tutum sergilenmiyorsa çevrenin, okuma alışkanlığı kazanma konusunda engelleyici bir rolü olabileceği görülmektedir (MEB, 2007: 3).

Okuma alışkanlığının kazandırılmasında, bazı bilişsel becerilerin gereklidir. Okuyucunun okuma davranışını kazanma sürecinin zorlu olması bilişsel gelişim ve okuma eylemi arasındaki ilişkiyi göstermektedir. illk okuma öğretiminde öncelikli amaçlardan biri okuma becerisini kazandırmaktır. Bu aşamadan sonraki evrede okuma yalnızca hedef olmanın haricinde, yeni bilgiler edinmek için bir vasıta şekline dönüşmektedir. Okuma etkinliğini pozitif veya negatif doğrultuda etkileyebilen bilişsel faktörler; görsel ve işitsel ayrımı fark etme yeteneği, yaş, zeka, algısal gelişim ve muhakeme becerileridir (Keleş, 2006: 29).

Anne-babasını kitap okurken gören çocuğun kitap okumaya ilişkin tutumları ile anne-babasında okuma alışkanlığı olmayan bir çocuğun tutumları farklı olacaktır (Alpoğuz, 2014). Kurnaz ve Yıldız'ın (2015) ortaokul öğrencilerinin okuma motivasyonlarını çeşitli değişkenler açısından incelemek amacıyla yaptığı çalışmanın sonucuna göre öğrencilerin okuma motivasyonu puanları, anne-babanın kitap okuma tutumuna göre değişkenlik göstermiştir. Anne-babası evde kitap okuyanların okuma motivasyonlarının, okumayanların okuma motivasyonundan daha yüksek olduğu belirlenmiştir. Okuma alışkanlığı, bir intiyaç olarak algılanarak okuma davranışının sürekli, düzenli ve eleştirel biçimde gerçekleştirilmesidir (Yılmaz, 2002: 116).

Okuma alışkanlığı, kişinin okumayı gereksinim olarak idrak etmesi ve hayat boyu düzenli biçimde devam ettirmesidir. Bu alışkanlık esasında formel eğitimin içerisinde kazandırılan bir davranıştır. Eğitim-öğretim sistemi içindeki bireyler bu sürecin içindeyken okuma alışkanlığını kazanmamışlarsa, ileriki dönemlerde kazanmaları daha zor gerçekleşir (Devrimci, 1993). Bir başka tanıma göre okuma alışkanlığı, bireyin okuma davranışına şartlanması ve güdülenmesine bağıı olarak bu davranışı alışkanlığa dönüştürmesini izleyen bir süreçtir (Güngördü, 2006).

Eğitim sürecinde bireye kazandırıması hedeflenen önemli etkinliklerden biri okuma alışkanlığıdır. Bireyin yaşadığı dünyayı doğru biçimde tanıyıp algılayarak çevresine uyum sağlaması yönünden de okuma alışkanlığının kazandııııması önem kazanmaktadır (Gömleksiz, 2004: 2). Çocuklar doğdukları andan itibaren ailelerini model olarak görürler. Çocuğun kazanacağı her davranışta olduğu gibi okuma becerisi kazanmaları konusunda da ailenin tutum ve davranışları oldukça önemlidir. Dolayısıyla akademik başarı elde etme ile ailelerin çocuklarına sundukları ortamın ilgisi olduğu düşünülmektedir.

Çocukların ailelerini bu derecede örnek aldıkları düşünüldüğünde akademik başarılarını etkileyen durumlar incelenmiş ve yapılan çoğu araştırmada (Alamdar, 2015; Ercik, 2016; Alpoğuz, 2014; Yıldız, 2016) ailenin tutum ve davranışlarının öğrencinin akademik başarısını etkilediği görülmüştür. Bu bağlamdan yola çıkılarak öğrencilerin anne-babalarının okuma tutumları ile akademik başarıları arasında bir ilişki olup olmadığının değerlendirilmesi gerektiği düşünülmüştür. Alanyazın incelendiğinde öğrencilerin okuma tutumları ile Türkçe dersi akademik başarıları arasındaki ilişkiyi inceleyen birçok araştırmanın bulunduğu görülmektedir (Acıyan, 2008; Dursun, 2018; Güngör, 2009). Ancak anne-babaların okuma tutumları ile öğrencilerin Türkçe dersi akademik başarısı arasındaki ilişkiyi inceleyen araştırmaya rastlanmamıştır. Ailenin dil becerilerinin öğrenimi üzerinde etkili olduğu bilindiğinden bu araştırmada anne-babaların okuma tutumları ile öğrencilerin Türkçe dersi akademik başarıları arasındaki ilişki incelenmiştir.

Araştırmanın temel amacı ilkokul 4. sınıf öğrencilerinin anne-babalarının okuma tutumları ile Türkçe dersi akademik başarıları arasında ilişkiyi saptamaktır. Bu amaç ile aşağıda belirtilen problemlere yanıt aranmıştır:

1. Anne-babaların okuma tutumları nasıldır?

2. Anne-babaların okuma tutumları cinsiyetlerine göre farklılaşmakta mıdır?

3. Anne-babaların okuma tutumları yaşlarına göre farklılaşmakta mıdır?

4. Anne-babaların okuma tutumları öğrenim durumlarına göre farklılaşmakta mıdır?

5. Anne-babaların okuma tutumları mesleklerine göre farklılaşmakta mıdır?

6. Anne-babaların okuma tutumları aylık gelirlerine göre farklılaşmakta mıdır?

7. Anne-babaların okuma tutumları çocuk sayılarına göre farklılaşmakta mıdır?

8. Anne-babaların okuma tutumları kitap okuma sıklıklarına göre farklılaşmakta mıdır? 
9. İlkokul 4. sınıf öğrencilerinin Türkçe dersi akademik başarıları ne düzeydedir?

10. İlkokul 4. sınıf öğrencilerinin Türkçe dersi akademik başarıları kitaplıklarının olup olmamasına göre değişmekte midir?

11. İlkokul 4. sınıf öğrencilerinin Türkçe dersi akademik başarıları anne-babalarının kitap okuma sıklıklarına göre değişmekte midir?

12. İlkokul 4. sınıf öğrencilerinin Türkçe dersi akademik başarıları ile anne-babalarının okuma tutumları arasında ilişki var mıdır?

\section{Araştırmanın Modeli}

\section{Yöntem}

Araştırmanın modeli tarama modellerinden ilişkisel tarama modelidir. Iki veya daha fazla değişken arasında bir değişim olup olmadığını, değişim varsa seviyesini tespit etmeyi hedefleyen araştırma modeli ilişkisel tarama modeli olarak tanımlanmaktadır. Bu modelde, aralarında ilişki araştırılacak değişkenler, tekli aramada yapıldığı gibi, ayrı ayrı simgeleştirilir. Fakat bu simgeleştirme (değer verme, ölçüm), ilişkisel bir çözümlemeye imkân sağlayacak veri çiftlerine uygulanır (Karasar, 2016: 114).

\section{Örneklem / Araştırma grubu}

Araştırmanın evreni, Çanakkale ili Merkez ilçesindeki ilkokullarda öğrenim gören 4. Sınıf öğrencileri ve onların anne-babalarından oluşmaktadır. Örneklem yöntemi olarak, seçkisiz örnekleme yöntemleri arasından basit seçkisiz örnekleme yöntemi seçilerek uygulanmıştır. Veri toplama araçlarını uygun biçimde doldurduğu belirlenen 203 veli araştırmaya dahil edilmiştir.

\section{Veri Toplama Araçları}

Bu araştırmada veri toplama aracı olarak anne-babaların okuma tutumlarını tespit etmek için araştırmacı tarafından geliştirilen "Okumaya Yönelik Tutum Ölçeği" ile anne-babaların demografik özelliklerini saptamak için "Kişisel Bilgi Formu" kullanılmıştır. Ölçeği geliştirmek amacıyla literatürdeki ilgili çalışmalar incelenmiştir. Yapılan incelemeler sonucunda anne-babaların okuma alışkanlığına yönelik araştırma soruları hazırlanarak tutum ifadelerine dönüştürülmüştür. Tutum ölçeğinin maddeleri hazırlanırken bilişsel, psikomotor ve duyuşsal alanlara ilişkin eşit dağııı yapılmasına dikkat edilmiştir.

\section{Okumaya Yönelik Tutum Ölçeği}

Araştırmacılar tarafından geliştirilen "Okumaya Yönelik Tutum Ölçeği” dört faktör altında yer alan 35 maddeden oluşmaktadır. Beşli likert türünde geliştirilen ölçekte tamamen katılıyorum 5, katılıyorum 4, kararsızım 3, katılmıyorum 2 ve hiç katılmıyorum 1 şeklinde puanlanmıştır. Birinci faktörde yer alan maddeler kitap okuma alışkanlığına ilişkin tutum, ikinci faktörde bulunan maddeler kitap okumanın yararlarına ilişkin tutum, üçüncü faktörde bulunan maddeler veli-kitap ilişkisi ile ilgili tutum, dördüncü faktörde yer alan maddeler ise çocuğu okumaya motive etmeye yönelik tutum olarak adlandırılmıştır. Birinci faktörde yer alan 1, 2, 3, 4, 5, 6, 7 ve 8. maddeler olumsuz maddeler olduğundan tersten puanlama yapılarak analiz edilmiştir.

\section{İşlem / Verilerin Toplanması}

Araştırmanın uygulanabilmesi için öncelikle Milli Eğitim Müdürlüğü’nden ilgili araştırma izni alınmıştır. Ana uygulama Çanakkale Merkez ilçesine bağlı ilkokullarda öğrenim gören 4. Sınıf öğrencilerinin anne-babalarına uygulanmıştır. Tutum ölçeği ve kişisel bilgi formu, 2019-2020 güz yarıyılında toplamda 203 ebeveyne uygulanmıştır. Korelasyon analizinde kullanılmak üzere öğrencilerin akademik başarılarını belirlemek için sınıf öğretmenlerinden 2019-2020 güz yarıyılı Türkçe dersi karne notları alınmıştır. 


\section{Verilerin Analizi}

Araştırmanın verileri, SPSS 22.0 (Statistical Package For Social Sciences) paket programı kullanılarak analiz edilmiştir. Veri toplama araçlarının geliştirilmesi ve uygulanmasıyla ulaşılan verilerin analizi için SPSS kullanılarak Frekans, Yüzde, Aritmetik Ortalama, Standart Sapma, t Testi, Anova Testi ve Pearson Korelasyon Katsayısı Testi uygulanmıştır.

\section{Geçerlik ve Güvenirlik}

Ön uygulama yapmak amacıyla hazırlanan tutum ölçeği ilgili literatür ve tutum konusunda yapılan çalışmalar çözümlenerek 62 maddelik bir deneme formu olarak hazırlanmıştır. Tutum ölçeği ve kişisel bilgi formu, 201 ilkokul 4. Sınıf öğrencisinin anne-babalarına uygulanmıştır. Testin kapsam geçerliği uzman görüşleri doğrultusunda belirlenmiştir. Yapı geçerliliğini saptamak için ise açımlayıcı faktör analizi uygulanmıştır.

Temel bileşenleri tespit etmek için dik döndürme yöntemi (varimax rotation) uygulanmıştır. Açıklanan toplam varyans değerleri incelendiğinde, analize alınan 38 maddenin (değişkenin), öz değeri 1 'den büyük olan 5 faktör altında toplandığı görülmektedir. Maddelerin ortak faktör varyanslarının 0.498 ile 0.744 arasında değer aldığı görülmektedir. Bu durum maddelerin ortak faktör varyanslarının yüksek olduğunu belirtmektedir. Analiz sonucunda, maddelerin faktörlere göre dağılımı incelenmiş ve iki faktör üzerinde yüksek değer alan 27 madde ölçekten çıkarılmıştır. Birinci faktörün varyans yüzdesinin \%20.353, ikinci faktörün varyans yüzdesinin \%15.844 ve üçüncü faktörün varyans yüzdesinin \%11.930 olduğu görülmektedir. Dört faktör birlikte, toplam varyansın \%48.228'ini açıklamaktadır. Maddelerin faktörlere göre dağııımı incelenmiş ve iki faktör üzerinde yüksek değer alan 27 madde ölçekten çıkarılmıştır. Maddelerin anlamları incelendiğinde; birinci faktörde $1,2,16,28,29,36,53$ ve 57 . maddeler, ikinci faktörde $4,7,8,9,10,11,14,15$ ve 21 . maddeler üçüncü faktörde $34,37,41,44,46,48,49,50$ ve 51 . maddeler, dördüncü faktörde ise $25,39,54,55,56,58,59,61$ ve 62. maddeler yer almaktadır. Ölçeğin güvenirliğinin belirlenmesi amacıyla yapılan analiz sonucu Cronbach Alpha katsayısı 0.80 olarak belirlenmiştir. Kişisel bilgi formu, araştırmaya dahil olan annebabaların demografik bilgilerini belirlemek amacıyla geliştirilmiştir. Bu kapsamda cinsiyet, yaş, öğrenim durumu, meslek, aylık gelir, çocuk sayısı, çocukların kendilerine ait kitaplıklarının olup olmadığı, kitap okuma sıklı̆ının belirlenmesinde 8 sorudan oluşan kişisel bilgi formu kullanılmıştır. Deneme formunun uygulanmasının ardından gerekli analizler yapılarak 35 maddelik bir tutum ölçeği araştırmacı tarafından hazırlanmıştır.

\section{Etik Kurulu İzni}

Araştırmanın verilerinin toplanması amacıyla ölçeğin geliştirilmesi için yapılan ön uygulama için Bursa İ Milli Eğitim Müdürlüğü’nden ve ana uygulama için Çanakkale il Milli Eğitim Müdürlüğü’nden gerekli izinler alınmıştır. Ayrıca araştırmanın ölçekleri sadece katılmaya gönüllü olan anne-babalara uygulanmıştır.

\section{Bulgular}

Araştırmanın birinci alt problemi "Anne-babaların okuma tutumları ne düzeydedir?" şeklinde ifade edilmiştir. Tablo 1'de anne-babaların okuma tutumlarına yönelik puan ortalamaları ve standart sapmaları verilmiştir.

Tablo 1.

Anne-Babaların Okuma Tutumlarına iliş̧kin Puan Ortalamaları ve Standart Sapma Sonuçları

\begin{tabular}{llllll}
\hline Okuma Tutumu & X & ss & Varyans & Min & Max \\
\hline Kitap Okuma Alışkanlığına İlişkin Tutum & 30.3547 & 6.86881 & 47.181 & 12.00 & 40.00 \\
Kitap Okumanın Yararlarına İlişkin Tutum & 34.1970 & 7.20290 & 51.882 & 9.00 & 45.00 \\
Veli-Kitap İlişkisi ile Illgili Tutum & 28.5717 & 7.81683 & 61.103 & 9.00 & 45.00 \\
Çocuğu Okumaya Motive Etmeye iliş̧in Tutum & 33.0690 & 7.27094 & 52.867 & 9.00 & 45.00 \\
Toplam & 126.1924 & 22.83426 & 521.404 & 67.00 & 171.00 \\
\hline
\end{tabular}


Okumaya yönelik tutum ölçeği $5^{\prime} l i$ likert ölçeği olduğu için alınabilecek maksimum puan 175'tir. Bu durumda tutum ölçeği toplamı için kesme noktaları 57 olarak belirlenmiştir. Yapılan analizlere göre 0-57 puanlar arası düşük, 58-114 puanlar arası orta ve 115-175 puanlar arası yüksek olarak belirlenmiştir. Faktörlerin kesme noktalarının belirlenmesi amacıyla madde sayısı ile seçenek sayısı çarpılarak alınabilecek maksimum toplam puan 3'e bölünmüştür. Bu durumda 1. faktörde 8 madde bulunduğu için alınabilecek maksimum puan 40 olarak belirlenmiştir. 1. faktör için 1-13 puan düşük, 14-26 puan orta ve 27-40 puan yüksek olarak belirlenmiştir. Benzer biçimde 2., 3. ve 4. faktörlerde 9 madde bulunduğu için 45 bulunmuş ve alınabilecek maksimum puan 45 olarak belirlenmiştir. 45, 3'e bölünerek 0-15 puan arası düşük, 16-30 puan orta ve 31-45 puan yüksek olarak belirlenmiştir.

Buna göre kitap okuma alışkanlığına ilişkin tutum ( $X=30.3547)$ yüksek düzeyde, kitap okumanın yararlarına ilişkin tutum ( $X=34.1970)$ yüksek düzeyde, veli kitap ilişkisi ile ilgili tutum ( $X=28.5717)$ orta düzeyde, çocuğu okumaya motive etmeye ilişkin tutum $(X=33.0690)$ yüksek düzeyde ve toplam tutum ( $X=126.1924)$ yüksek düzeyde olarak belirlenmiştir.

Verilerin analizinde kullanılacak olan istatistik yöntemini belirlemek amacıyla öncelikle ölçek dağılımının normal dağıııma uyup uymadığını belirlemek amacıyla anne-babaların kitap okuma ilişkin tutum ölçeğinden almış oldukları puanlara Kolmogorov-Smirnov testi uygulanmıştır. Kolmogorov Smirnov testi sonucu Tablo 2'de verilmiştir.

Tablo 2.

Anne-Babaların Kitap Okuma ilişskin Tutum Ölçeğinden Aldıkları Puanlara ilişsin Kolmogorov- Smirnov Değerleri

\begin{tabular}{llll}
\hline Ölçek & Statistic & sd & Sig \\
\hline Kitap Okuma İlişkin Tutum Ölçeği & 0.099 & 203 & 0.00 \\
\hline
\end{tabular}

Ölçekten alınan Kolmogorov-Smirnov değerleri incelendiğinde, dağııımın normal dağıııma uygun olduğu görülmektedir. Bu sebeple araştırmanın alt problemlerinin çözümlenmesinde parametrik testlerin kullanılması uygun görülmüştür.

Araştırmanın ikinci alt problemi "Anne-babaların okuma tutumları cinsiyetlerine göre farklılaşmakta mıdır?" şeklinde ifade edilmiştir. Tablo 10'da anne-babaların cinsiyetleri ile okuma tutumlarına yönelik $\mathrm{t}$ testi sonuçları sunulmuştur.

Tablo 3.

Anne-Babaların Cinsiyetleri ile Okuma Tutumlarına ilişkin t Testi Sonuçları

\begin{tabular}{cccccccc}
\hline & Cinsiyet & $\mathrm{N}$ & $\overline{\mathrm{X}}$ & $\mathrm{s}$ & $\mathrm{sd}$ & $\mathrm{t}$ & $\mathrm{p}$ \\
\hline Kitap Okuma Alışkanlığına İlişkin & Kadın & 133 & 31.2707 & 6.79586 & 201 & 2.658 & $0.008^{*}$ \\
Tutum & Erkek & 70 & 28.6143 & 6.71424 & & & \\
Kitap Okumanın Yararlarına İlişkin & Kadın & 133 & 34.4662 & 7.36037 & 201 & 0.733 & 0.464 \\
Tutum & Erkek & 70 & 33.6857 & 6.91678 & & & \\
Veli-Kitap İlişkisi İle İlgili Tutum & Kadın & 133 & 28.8274 & 7.82481 & 201 & 0.642 & 0.522 \\
& Erkek & 70 & 28.0857 & 7.83478 & & & \\
Çocuğu Okumaya Motive Etmeye & Kadın & 133 & 33.7293 & 7.10007 & 201 & 1.793 & 0.074 \\
İlişkin Tutum & Erkek & 70 & 31.8143 & 7.47613 & & & \\
Toplam Tutum & Kadın & 133 & 128.2936 & 22.50612 & 201 & 1.818 & 0.071 \\
& Erkek & 70 & 122.2000 & 23.08121 & & & \\
\hline
\end{tabular}

$* p<0,05$

Tablo 3 incelendiğinde, anne-babaların okuma tutumlarının cinsiyetlere göre yalnızca 1. faktörde anlamlı bir farklılaşma gösterdiği $[t(201)=2.658, p<0,05]$, diğer faktörlerde anlamlı bir farklılı̆ın olmadığı görülmektedir. Diğer bir deyişle, kadınların kitap okuma alışkanlığına ilişkin tutumları erkeklerden daha yüksektir. Kitap okumanın yararlarına ilişkin tutum, veli-kitap ilişkisi, 
ilkokul 4. Sınıf Öğrencilerinin Anne-Babalarının Okuma Tutumları ile Türkçe Dersi Akademik Başarısı Arasındaki ilişki

çocuğu okumaya motive etmeye ilişkin tutum ve toplam tutum puanlarında kadınlar ile erkekler arasında anlamlı fark görülmemiştir.

Araştırmanın üçüncü alt problemi "Anne-babaların okuma tutumları yaşlarına göre farklılaşmakta mıdır?" şeklinde ifade edilmiştir. Tablo 4'de anne-babaların yaşları ile okuma tutumlarına yönelik ANOVA sonuçları sunulmuştur.

Tablo 4.

Anne-Babaların Yaşları ile Okuma Tutumlarına ilişskin ANOVA Sonuçları

\begin{tabular}{|c|c|c|c|c|c|c|}
\hline & $\begin{array}{l}\text { Varyansın } \\
\text { Kaynağı }\end{array}$ & $\begin{array}{l}\text { Kareler } \\
\text { Toplamı }\end{array}$ & $\mathrm{Sd}$ & $\begin{array}{l}\text { Kareler } \\
\text { Ortalaması }\end{array}$ & $\mathrm{F}$ & $\mathrm{P}$ \\
\hline \multirow{6}{*}{$\begin{array}{l}\text { Kitap Okuma } \\
\text { Alışkanlığına } \\
\text { ilişkin Tutum } \\
\text { Kitap } \\
\text { Okumanın } \\
\text { Yararlarına } \\
\text { Illişkin Tutum }\end{array}$} & Gruplar arası & 134.950 & 3 & 44.983 & 0.956 & 0.415 \\
\hline & Gruplar içi & 9320.401 & 198 & 47.073 & & \\
\hline & Toplam & 9455.351 & 201 & & & \\
\hline & Gruplar arası & 27.156 & 3 & 9.052 & 0.172 & 0.916 \\
\hline & Gruplar içi & 10449.70 & 198 & 52.776 & & \\
\hline & Toplam & 10476.85 & 201 & & & \\
\hline \multirow{3}{*}{$\begin{array}{l}\text { Veli-Kitap } \\
\text { illişkisi ile İlgili } \\
\text { Tutum }\end{array}$} & Gruplar arası & 39.387 & 3 & 13.129 & 0.214 & 0.886 \\
\hline & Gruplar içi & 12122.17 & 198 & 61.223 & & \\
\hline & Toplam & 12161.56 & 201 & & & \\
\hline \multirow{4}{*}{$\begin{array}{l}\text { Çocuğu Kitap } \\
\text { Okumaya } \\
\text { Motive Etmeye } \\
\text { iliş̧in Tutum }\end{array}$} & Gruplar arası & 48.059 & 3 & 16.020 & 0.301 & 0.825 \\
\hline & Gruplar içi & 10531.86 & 198 & 53.191 & & \\
\hline & Toplam & 10579.92 & 201 & & & \\
\hline & Gruplar arası & 433.519 & 3 & 144.506 & 0.276 & 0.843 \\
\hline \multirow[t]{2}{*}{ Toplam Tutum } & Gruplar içi & 103741.4 & 198 & 523.946 & & \\
\hline & Toplam & 104174.9 & 201 & & & \\
\hline
\end{tabular}

Analiz sonuçları incelendiğinde alt faktörlerde ve toplam tutumda anne-babaların yaşlarına göre okuma tutumlarında anlamlı farklılığa rastlanmamıştır $[F(3-198)=0.276, p<0,05]$. Başka bir deyişle anne-babaların okuma tutumları, yaşlarına bağlı olarak değişkenlik göstermemektedir.

Araştırmanın dördüncü alt problemi "Anne-babaların okuma tutumları öğrenim durumlarına göre farklılaşmakta mıdır?" şeklinde ifade edilmiştir. Tablo 5'te anne-babaların öğrenim durumları ile okuma tutumlarına yönelik ANOVA testi sonuçları sunulmuştur.

Tablo 5.

Anne-Babaların Öğrenim Durumları ile Okuma Tutumlarına Ilişskin ANOVA Sonuçları

\begin{tabular}{|c|c|c|c|c|c|c|}
\hline & $\begin{array}{l}\text { Varyansın } \\
\text { Kaynağı }\end{array}$ & $\begin{array}{l}\text { Kareler } \\
\text { Toplamı }\end{array}$ & $\mathrm{Sd}$ & $\begin{array}{l}\text { Kareler } \\
\text { Ortalaması }\end{array}$ & $\mathrm{F}$ & $P$ \\
\hline Kitap Okuma & Gruplar arası & 639.748 & 5 & 127.950 & 2.835 & 0.017 \\
\hline \multirow{2}{*}{$\begin{array}{l}\text { Alışkanlığına } \\
\text { iliş̧kin Tutum }\end{array}$} & Gruplar içi & 8890.715 & 197 & 45.131 & & \\
\hline & Toplam & 9530.463 & 202 & & & \\
\hline \multirow{3}{*}{$\begin{array}{l}\text { Kitap } \\
\text { Okumanın } \\
\text { Yararlarına } \\
\text { İlişkin Tutum }\end{array}$} & Gruplar arası & 1105.613 & 5 & 221.123 & 4.647 & $0.000 *$ \\
\hline & Gruplar içi & 9374.505 & 197 & 47.586 & & \\
\hline & Toplam & 10480.12 & 202 & & & \\
\hline
\end{tabular}




\begin{tabular}{lllllll} 
Veli-Kitap & Gruplar arası & 381.651 & 5 & 76.330 & 1.257 & 0.284 \\
iliş̧kisi ile ilgili & Gruplar içi & 11961.12 & 197 & 60.716 & & \\
Tutum & Toplam & 12342.77 & 202 & & & \\
Çocuğu Kitap & Gruplar arası & 804.878 & 5 & 160.976 & 3.212 & $0.008^{*}$ \\
$\begin{array}{l}\text { Okumaya } \\
\text { Motive Etmeye }\end{array}$ & Gruplar içi & 9874.156 & 197 & 50.123 & & \\
$\begin{array}{l}\text { Ilişskin Tutum } \\
\text { Toplam Tutum }\end{array}$ & Toplam & 10679.03 & 202 & & & \\
& Gruplar arası & 9380.612 & 5 & 1876.122 & 3.852 & $0.002^{*}$ \\
& Gruplar içi & 95942.90 & 197 & 487.020 & & \\
\hline
\end{tabular}

$* p<0,05$

Analiz sonuçları incelendiğinde anne-babaların öğrenim durumlarına göre okuma tutumlarında toplam tutum ile 1., 2. ve 4. faktörlerde anlamlı bir fark görülmüştür. Öğrenim durumu bakımından anlamlı farklıı̆ın hangi gruplar arasında olduğunu belirtmek için Tukey testi uygulanmıştır. Tukey testinin sonuçları incelendiğinde toplam tutumda öğrenim durumu okuryazar olan ile üniversite olan anne-babalar arasında öğrenim durumu üniversite olan anne-babalar lehine anlamlı bir farklılık olduğu görülmüştür $[F(5-197)=3.852, p<0,05]$. 1. faktörde öğrenim durumu ortaokul ile üniversite olan annebabalar arasında öğrenim durumu üniversite olan anne-babalar lehine anlamlı bir farklılık ortaya çıkmıştır [F(5-197)= 2.835, $p<0,05]$.

2. faktörde öğrenim durumu üniversite olan anne-babalar ile okuryazar olan ve ilkokul olan anne-babalar arasında öğrenim durumu üniversite olan anne-babalar lehine anlamlı bir farklılaşma ortaya çıkmıştır $[F(5-197)=4.647, p<0,05]$.

4. faktörde öğrenim durumu okuryazar ile lise, üniversite ve lisansüstü olan anne-babalar arasında öğrenim durumu lise olanlar lehine anlamlı bir farklılık olduğu ortaya çıkmıştır. Bunun yanı sıra öğrenim durumu ilkokul olanlar ile lise olanlar arasında öğrenim durumu lise olan anne-babaların lehine, öğrenim durumu ilkokul olanlar ile üniversite olanlar arasında öğrenim durumu üniversite olan anne-babalar lehine anlamlı farklılık olduğu görülmektedir $[F(5-197)=3.212, p<0,05]$.

Araştırmanın beşinci alt problemi "Anne-babaların okuma tutumları mesleklerine göre farklılaşmakta mıdır?" şeklinde ifade edilmiştir. Tablo 6'da anne-babaların meslekleri ile okuma tutumlarına yönelik ANOVA testi sonuçları sunulmuştur.

Tablo 6.

Anne-Babaların Meslekleri ile Okuma Tutumlarına iliş̧kin ANOVA Sonuçları

\begin{tabular}{|c|c|c|c|c|c|c|}
\hline & $\begin{array}{l}\text { Varyansın } \\
\text { Kaynağı }\end{array}$ & $\begin{array}{l}\text { Kareler } \\
\text { Toplamı } \\
\end{array}$ & Sd & $\begin{array}{l}\text { Kareler } \\
\text { Ortalaması }\end{array}$ & $\mathrm{F}$ & $\mathrm{P}$ \\
\hline Kitap Okuma & Gruplar arası & 307.314 & 7 & 43.902 & 0.928 & 0.486 \\
\hline Alışkanlığına & Gruplar içi & 9223.149 & 195 & 47.298 & & \\
\hline İlişkin Tutum & Toplam & 9530.463 & 202 & & & \\
\hline $\begin{array}{l}\text { Kitap } \\
\text { Okumanın }\end{array}$ & Gruplar arası & 644.780 & 7 & 92.111 & 1.826 & 0.084 \\
\hline $\begin{array}{l}\text { Yararlarına } \\
\text { ilişskin Tutum }\end{array}$ & Gruplar içi & 9835.338 & 195 & 50.438 & & \\
\hline & Toplam & 10480.12 & 202 & & & \\
\hline Veli-Kitap & Gruplar arası & 629.848 & 7 & 89.978 & 1.498 & 0.170 \\
\hline İlişkisi ile İlgili & Gruplar içi & 11712.92 & 195 & 60.066 & & \\
\hline Tutum & Toplam & 12342.77 & 202 & & & \\
\hline Çocuğu Kitap & Gruplar arası & 234.855 & 7 & 33.551 & 0.626 & 0.734 \\
\hline Okumaya & Gruplar içi & 10444.18 & 195 & 53.560 & & \\
\hline $\begin{array}{l}\text { Motive Etmeye } \\
\text { ilişkin Tutum }\end{array}$ & Toplam & 10679.03 & 202 & & & \\
\hline
\end{tabular}


ilkokul 4. Sınıf Öğrencilerinin Anne-Babalarının Okuma Tutumları ile Türkçe Dersi Akademik Başarısı Arasındaki ilişki

\begin{tabular}{lllllll} 
Toplam Tutum & Gruplar arası & 4739.213 & 7 & 677.030 & 1.313 & 0.246 \\
& Gruplar içi & 100584.3 & 195 & 515.817 & & \\
& Toplam & 105323.5 & 202 & & & \\
\hline
\end{tabular}

$* p<0,05$

Analiz sonuçları incelendiğinde toplam tutumda ve alt boyutlarda anne-babaların mesleklerine göre okuma tutumlarında anlamlı bir fark görülmemiştir $[F(7-195)=1.313, p<0,05]$. Diğer bir ifade ile anne-babaların okuma tutumları, mesleklerine bağlı olarak değişkenlik göstermemektedir.

Araştırmanın altıncı alt problemi "Anne-babaların okuma tutumları aylık gelirlerine göre farklılaşmakta mıdır?" şeklinde ifade edilmiştir. Tablo 7'de anne-babaların aylık gelirleri ile okuma tutumlarına yönelik ANOVA testi sonuçları sunulmuştur.

Tablo 7.

Anne-Babaların Aylık Gelirleri ile Okuma Tutumlarına iliş̧kin ANOVA Sonuçları

\begin{tabular}{|c|c|c|c|c|c|c|}
\hline & $\begin{array}{l}\text { Varyansın } \\
\text { Kaynağı }\end{array}$ & $\begin{array}{l}\text { Kareler } \\
\text { Toplamı }\end{array}$ & $\mathrm{Sd}$ & $\begin{array}{l}\text { Kareler } \\
\text { Ortalaması }\end{array}$ & $\mathrm{F}$ & $P$ \\
\hline Kitap Okuma & Gruplar arası & 463.715 & 7 & 66.245 & 1.425 & 0.197 \\
\hline \multirow{2}{*}{$\begin{array}{l}\text { Alışkanlığına } \\
\text { illişkin Tutum }\end{array}$} & Gruplar içi & 9066.749 & 195 & 46.496 & & \\
\hline & Toplam & 9530.463 & 202 & & & \\
\hline \multicolumn{7}{|l|}{ Okumanın } \\
\hline \multirow[t]{2}{*}{$\begin{array}{l}\text { Yararlarına } \\
\text { illişkin Tutum }\end{array}$} & Gruplar içi & 9556.986 & 195 & 49.010 & & \\
\hline & Toplam & 10480.12 & 202 & & & \\
\hline \multirow{3}{*}{$\begin{array}{l}\text { Veli-Kitap } \\
\text { iliş̧kisi ile ilgili } \\
\text { Tutum }\end{array}$} & Gruplar arası & 660.424 & 7 & 94.346 & 1.575 & 0.145 \\
\hline & Gruplar içi & 11682.34 & 195 & 59.909 & & \\
\hline & Toplam & 12342.77 & 202 & & & \\
\hline \multirow{6}{*}{$\begin{array}{l}\text { Çocuğu Kitap } \\
\text { Okumaya } \\
\text { Motive Etmeye } \\
\text { İlişkin Tutum } \\
\text { Toplam Tutum }\end{array}$} & Gruplar arası & 656.292 & 7 & 93.756 & 1.824 & 0.085 \\
\hline & Gruplar içi & 10022.74 & 195 & 51.399 & & \\
\hline & Toplam & 10679.03 & 202 & & & \\
\hline & Gruplar arası & 7721.666 & 7 & 1103.095 & 2.204 & $0.036^{*}$ \\
\hline & Gruplar içi & 97601.84 & 195 & 500.522 & & \\
\hline & Toplam & 105323.5 & 202 & & & \\
\hline
\end{tabular}

$* p<0,05$

Analiz sonuçları incelendiğinde toplam tutumda ve 2 . faktörde anne-babaların aylık gelirlerine göre okuma tutumlarında anlamlı bir farklılık ortaya çıkmıştır. Aylık gelir bakımından anlamlı farkın hangi gruplar arasında olduğunu belirtmek için Tukey testi uygulanmıştır. Tukey testinin sonuçlarına göre toplam tutumda aylık geliri 4000 ve üzeri olanlar ile 1-1500 olanlar, 2000-2500 olanlar ve 30003500 olanlar arasında anlamlı farklılık görülmüştür. Bu anlamlı farkın aylık geliri 4000 ve üzeri olanlar lehine olduğu belirlenmiştir. 2. faktörde çıkan anlamlı fark ise aylık geliri 4000 ve üzeri olanlar ile 11500 olanlar ve 2001-2500 olanlar arasında aylık geliri 4000 ve üzeri olanlar lehine, aylık geliri 20012500 olanlar ile 3501-4000 olanlar arasında 3501-4000 olanlar lehine anlamlı farklılık olduğu belirlenmiştir. Ayrıca aylık geliri 2501-3000 olanlar ile 1-1500 olanlar ve 2001-2500 olanlar arasında 2501-3000 olanlar lehine anlamlı farklılık saptanmıştır.

Araştırmanın yedinci alt problemi "Anne-babaların okuma tutumları çocuk sayılarına göre farklılaşmakta mıdır?" şeklinde ifade edilmiştir. Tablo 8'de anne-babaların çocuk sayıları ile okuma tutumlarına yönelik ANOVA testi sonuçları sunulmuştur. 
Tablo 8.

Anne-Babaların Çocuk Sayıları ile Okuma Tutumlarına iliş̧kin ANOVA Sonuçları

\begin{tabular}{|c|c|c|c|c|c|c|}
\hline & $\begin{array}{l}\text { Varyansın } \\
\text { Kaynağı }\end{array}$ & $\begin{array}{l}\text { Kareler } \\
\text { Toplamı }\end{array}$ & Sd & $\begin{array}{l}\text { Kareler } \\
\text { Ortalaması }\end{array}$ & $\mathrm{F}$ & $P$ \\
\hline Kitap Okuma & Gruplar arası & 76.957 & 3 & 25.652 & 0.540 & 0.655 \\
\hline \multirow{2}{*}{$\begin{array}{l}\text { Alışkanlığına } \\
\text { İlişkin Tutum }\end{array}$} & Gruplar içi & 9453.506 & 199 & 47.505 & & \\
\hline & Toplam & 9530.463 & 202 & & & \\
\hline $\begin{array}{l}\text { Kitap } \\
\text { Okumanın }\end{array}$ & Gruplar arası & 255.385 & 3 & 85.128 & 1.657 & $0.178 *$ \\
\hline \multirow{2}{*}{$\begin{array}{l}\text { Yararlarına } \\
\text { İlişkin Tutum }\end{array}$} & Gruplar içi & 10224.73 & 199 & 51.381 & & \\
\hline & Toplam & 10480.12 & 202 & & & \\
\hline \multirow{3}{*}{$\begin{array}{l}\text { Veli-Kitap } \\
\text { İlişkisi ile İlgili } \\
\text { Tutum }\end{array}$} & Gruplar arası & 56.817 & 3 & 18.939 & 0.307 & 0.820 \\
\hline & Gruplar içi & 12285.95 & 199 & 61.738 & & \\
\hline & Toplam & 12342.77 & 202 & & & \\
\hline \multirow{6}{*}{$\begin{array}{l}\text { Çocuğu Kitap } \\
\text { Okumaya } \\
\text { Motive Etmeye } \\
\text { İlişkin Tutum } \\
\text { Toplam Tutum }\end{array}$} & Gruplar arası & 149.915 & 3 & 49.972 & 0.944 & 0.420 \\
\hline & Gruplar içi & 10529.12 & 199 & 52.910 & & \\
\hline & Toplam & 10679.03 & 202 & & & \\
\hline & Gruplar arası & 1437.483 & 3 & 479.161 & 0.918 & 0.433 \\
\hline & Gruplar içi & 103886.0 & 199 & 522.040 & & \\
\hline & Toplam & 105323.5 & 202 & & & \\
\hline
\end{tabular}

$* p<0,05$

Analiz sonuçları incelendiğinde toplam tutumda ve alt faktörlerde anne-babaların çocuk sayılarına göre okuma tutumlarında anlamlı farklılığa rastlanmamıştır $[F(3-199)=0.918, p<0,05]$. Başka bir deyişle anne-babaların okuma tutumları, çocuk sayısına bağlı olarak değişkenlik göstermemektedir.

Araştırmanın sekizinci alt problemi "Anne-babaların okuma tutumları kitap okuma sıklıklarına göre farklılaşmakta mıdır?” şeklinde ifade edilmiştir. Tablo 9'da anne-babaların kitap okuma sıklıkları ile okuma tutumlarına ilişkin ANOVA testi sonuçları sunulmuştur.

Tablo 9.

Anne-Babaların Kitap Okuma Sıklıkları ile Okuma Tutumlarına Illişkin ANOVA Sonuçları

\begin{tabular}{|c|c|c|c|c|c|c|}
\hline & $\begin{array}{l}\text { Varyansın } \\
\text { Kaynağı }\end{array}$ & $\begin{array}{l}\text { Kareler } \\
\text { Toplamı }\end{array}$ & Sd & $\begin{array}{l}\text { Kareler } \\
\text { Ortalaması }\end{array}$ & $\mathrm{F}$ & $\mathrm{P}$ \\
\hline Kitap Okuma & Gruplar arası & 1871.336 & 4 & 467.834 & 12.094 & $0.000 *$ \\
\hline \multirow{2}{*}{$\begin{array}{l}\text { Alışkanlığına } \\
\text { iliş̧kin Tutum }\end{array}$} & Gruplar içi & 7659.127 & 198 & 38.682 & & \\
\hline & Toplam & 9530.463 & 202 & & & \\
\hline $\begin{array}{l}\text { Kitap } \\
\text { Okumanın }\end{array}$ & \multicolumn{5}{|c|}{ Okumanın } & $0.000 *$ \\
\hline \multirow{2}{*}{$\begin{array}{l}\text { Yararlarına } \\
\text { İlişkin Tutum }\end{array}$} & Gruplar içi & 9231.797 & 198 & 46.625 & & \\
\hline & Toplam & 10480.12 & 202 & & & \\
\hline Veli-Kitap & Gruplar arası & 2968.660 & 4 & 742.165 & 15.676 & $0.000 *$ \\
\hline İlişkisi ile İlgili & Gruplar içi & 9374.109 & 198 & 47.344 & & \\
\hline Tutum & Toplam & 12342.77 & 202 & & & \\
\hline Çocuğu Kitap & Gruplar arası & 1335.303 & 4 & 333.826 & 7.074 & $0.000 *$ \\
\hline Okumaya & Gruplar içi & 9343.732 & 198 & 47.191 & & \\
\hline $\begin{array}{l}\text { Motive Etmeye } \\
\text { ilişkin Tutum }\end{array}$ & Toplam & 10679.03 & 202 & & & \\
\hline
\end{tabular}


ilkokul 4. Sınıf Öğrencilerinin Anne-Babalarının Okuma Tutumları ile Türkçe Dersi Akademik Başarısı Arasındaki ilişki

\begin{tabular}{lllllll} 
Toplam Tutum & Gruplar arası & 27173.77 & 4 & 6793.442 & 17.212 & $0.000^{*}$ \\
& Gruplar içi & 78149.74 & 198 & 394.696 & & \\
& Toplam & 105323.5 & 202 & & & \\
\hline
\end{tabular}

$* p<0,05$

Analiz sonuçları incelendiğinde toplam tutumda ve tüm alt faktörlerde anne-babaların kitap okuma sıklıklarına göre okuma tutumlarında anlamlı bir fark görülmüştür. Diğer bir ifade ile annebabaların okuma tutumları, kitap okuma sıklıklarına bağlı olarak değişkenlik göstermektedir. Gruplar arasında gözlenen anlamlı farkın, hangi gruplar arasındaki anlamlı farklara bağlı olarak çıktığını belirlemek amacıyla Tukey testi uygulanmıştır. Tukey testi sonuçlarına göre toplam tutumda hiç okumam diyenlerle 0-5 okurum, 6-10 okurum, 11-15 okurum ve 15 ve üzeri okurum diyenler arasında 0-5 okurum, 6-10 okurum, 11-15 okurum ve 15 ve üzeri okurum diyenler lehine anlamlı bir farklılık olduğu ortaya çıkmıştır. Ayrıca toplam tutumda 15 ve üzeri okurum diyenler ile hiç okumam, 0-5 okurum, 6-10 okurum diyenler arasında 15 ve üzeri okurum diyenler lehine anlamlı farklılık gözlenmiştir.

1. faktörde kitap okuma alışkanlığına ilişkin tutumlar incelenmiş ve hiç okumam diyenlerle diğer seçenekler arasında diğer seçenekler lehine anlamlı farklılık görülmüştür. 15 ve üzeri okurum diyenlerle hiç okumam, 0-5 okurum, 6-10 okurum diyenler arasında 15 ve üzeri okurum diyenler lehine anlamlı farklılık ortaya çıkmıştır. 2. faktörde kitap okumanın yararlarına ilişkin tutumlar incelenmiş ve hiç okumam diyenler ile 0-5 okurum diyenler arasında 0-5 okurum diyenler lehine, hiç okumam diyenler ile 11-15 okurum diyenler arasında 11-15 okurum diyenler lehine, hiç okumam diyenlerle 15 ve üzeri okurum diyenler arasında 15 ve üzeri okurum diyenler lehine, 15 ve üzeri okurum diyenler ile 0-5 okurum, 6-10 okurum diyenler arasında 15 ve üzeri okurum diyenler lehine anlamlı bir farklılık olduğu görülmüştür. 3. faktörde veli-kitap ilişkisi incelenmiş ve hiç okumam diyenler ile 11-15 okurum diyenler arasında 11-15 okurum diyenler lehine, hiç okumam diyenler ile 15 ve üzeri okurum diyenler arasında 15 ve üzeri okurum diyenler lehine, 15 ve üzeri okurum diyenler ile 6-10 okurum, 0-5 okurum diyenler arasında 15 ve üzeri okurum diyenler lehine anlamlı farklılık olduğu ortaya çıkmıştır. 4. faktör ise çocuğu okumaya motive etmek olarak adlandırılmış ve 15 ve üzeri okurum diyenler ile hiç okumam, 0-5 okurum, 6-10 okurum diyenler arasında 15 ve üzeri okurum diyenler lehine anlamlı farklılık görülmüştür.

Araştırmanın dokuzuncu alt problemi "ilkokul 4. Sınıf öğrencilerinin Türkçe dersi akademik başarıları ne düzeydedir?" şeklinde ifade edilmiştir. Tablo 10'da ilkokul 4. Sınıf öğrencilerinin Türkçe dersi akademik başarılarına yönelik puan ortalamaları ve standart sapmaları verilmiştir.

Tablo 10.

Ilkokul 4. Sınıf Öğrencilerinin Türkçe Dersi Akademik Başarılarına iliş̧kin Puan Ortalamaları ve Standart Sapma Sonuçları

\begin{tabular}{llllll}
\hline $\begin{array}{l}\text { Okuma } \\
\text { Tutumu }\end{array}$ & $\overline{\mathrm{X}}$ & Ss & Varyans & $\min$ & Max \\
\hline & 89.9048 & 6.26208 & 39.214 & 73.00 & 100.00 \\
\hline
\end{tabular}

Tablo 10 incelendiğinde ilkokul 4. Sınıf öğrencilerin Türkçe dersi akademik başarılarının yüksek düzeyde olduğu (X=89.9048; SS=6.26208) görülmektedir.

Araştırmanın onuncu alt problemi "ilkokul 4. Sınıf öğrencilerinin Türkçe dersi akademik başarıları kitaplıklarının olup olmamasına göre değişmekte midir?" şeklinde ifade edilmiştir. Tablo $11^{\prime}$ de çocukların kitaplıklarının varlığı ile akademik başarılarına ilişkin t testinin sonuçları sunulmuştur.

Tablo 11.

Çocukların Kitaplıklarının Varlığı ile Türkçe Dersi Akademik Başarılarına ilişskin t Testi Sonuçları

$\begin{array}{llllllll}\text { Kitaplık } & N & \bar{X} & S & s d & t & p\end{array}$




\begin{tabular}{llllllll}
\hline Toplam & Var & 188 & 89.8096 & 6.30302 & 201 & -0.766 & 0.445 \\
& Yok & 15 & 91.0980 & 5.78760 & & & \\
& & & & & & & \\
\end{tabular}

$* p<0,05$

Tablo 11 incelendiğinde, çocukların kitaplıklarının varlığına göre Türkçe dersi akademik başarılarında anlamlı bir farklılık olmadığı görülmektedir [t (201)=-0.766, <0.005]. Diğer bir deyişle çocukların Türkçe dersi akademik başarıları kitaplıklarının varlığına göre değişkenlik göstermemektedir.

Araştırmanın on birinci alt problemi "illkokul 4. Sınıf öğrencilerinin Türkçe dersi akademik başarıları anne-babalarının kitap okuma sıklıklarına göre değişmekte midir?" şeklinde ifade edilmiştir. Tablo 12'de anne-babaların kitap okuma sıklıkları ile çocukların Türkçe dersi akademik başarılarına yönelik ANOVA testi sonuçları sunulmuştur.

Tablo 12.

Anne-Babaların Kitap Okuma Sıklıkları ile Çocukların Türkçe Dersi Akademik Başarılarına ilişskin ANOVA Testi Sonuçları

\begin{tabular}{lllllll}
\hline & $\begin{array}{l}\text { Varyansın } \\
\text { Kaynağı }\end{array}$ & $\begin{array}{l}\text { Kareler } \\
\text { Toplamı }\end{array}$ & Sd & $\begin{array}{l}\text { Kareler } \\
\text { Ortalaması }\end{array}$ & F & P \\
\hline Toplam & Gruplar arası & 210.204 & 4 & 52.551 & 1.349 & 0.253 \\
& Gruplar içi & 7710.943 & 198 & 38.944 & & \\
& Toplam & 7921.147 & 202 & & & \\
\hline
\end{tabular}

$* p<0,05$

Analiz sonuçlarına bakıldığında anne-babaların kitap okuma sıklıklarına göre çocukların Türkçe dersi akademik başarılarında anlamlı bir fark görülmemiştir $[F(4-198)=1.349, p<0,05]$. Diğer bir deyişle çocukların Türkçe dersi akademik başarıları, anne-babalarının kitap okuma sıklıklarına bağlı olarak değişkenlik göstermemektedir.

Araştırmanın on ikinci alt problemi "ilkokul 4. Sınıf öğrencilerinin Türkçe dersi akademik başarıları anne-babalarının okuma tutumları arasında ilişki var mıdır?" şeklinde ifade edilmiştir. Tablo 13 'de anne-babaların okuma tutumları ile çocukların Türkçe dersi akademik başarılarına ilişkin Pearson Korelasyon Katsayısı testi sonuçları sunulmuştur.

Tablo 13.

Öğrencilerinin Türkçe Dersi Akademik Başarıları ile Anne Babalarının Okuma Tutumları Arasındaki Pearson Korelasyon Katsayısı Testi Sonuçları

\begin{tabular}{lll}
\hline \multirow{2}{*}{ Akademik Başarı } & Pearson & 0,185 \\
& Korelasyon Katsayısı & \\
Sig & 0,008 \\
N & 203 \\
\hline
\end{tabular}

Analiz sonuçlarına göre ilkokul 4. Sınıf öğrencilerinin Türkçe dersi akademik başarıları ile anne babalarının okuma tutumları arasında hesaplanan korelasyon katsayısı 0,185 ( $p=0,001)$ olup düşük düzeyde anlamlı ve pozitif bir ilişkiye rastlanmıştır.

\section{Tartışma ve Sonuç}

Araştırmanın birinci alt probleminde anne-babaların okuma tutumlarının ne düzeyde olduğu belirlenmeye çalışılmıştır. Araştırma sonuçları incelendiğinde anne-babaların kitap okuma alışkanlığına ilişkin tutumun yüksek düzeyde, kitap okumanın yararlarına ilişkin tutumun yüksek düzeyde, çocuğu okumaya motive etmeye ilişkin tutumun yüksek düzeyde, toplam tutum puanının yüksek düzeyde ve veli kitap ilişkisi ile ilgili tutumun orta düzeyde olduğu belirlenmiştir. Öztürk ve Yiğit'in (2016), ilkokulda öğrenim gören öğrencilerin okuma alışkanlığı düzeylerini ebeveynlerinin görüşleri yönünde belirlemeyi 
amaçladığı çalışmanın sonuçları incelendiğinde; ebeveynlerine göre ilkokul öğrencilerinin büyük bir bölümünün kitap okumaktan keyif almasına rağmen yarısından çoğunun okuma alışkanlığına sahip olduğu, diğerlerinin ise bu alışkanlığa sahip olmadığı görülmüştür. Ebeveynlerin \%64.8'i çocuklarının bu alışkanlığa sahip olduğunu, \%35.2'si ise olmadığını ifade etmiştir. Ebeveynlerin \%74.1'i çocuğuna okuma alışkanlığını edindirmek amacıyla öğretmenleri ile işbirliği içindedir. Ebeveynlerin yalnızca \%38.0'i okuma konusunda örnek olabilecek davranışlar gösterdiğini ifade ederken büyük çoğunluğu (\%74.1) okumanın neden önemli olduğundan bahsettiğini ve \%56.5'i çocuğuna okuması için sürekli uyarılarda bulunduğunu belirttikleri görülmüştür. Araştırmanın bulguları bu araştırmanın bulguları ile örtüşmektedir. Nazlı (2016), yaptığı araştırmada çocukların okuma alışkanlığı edinmesi aşamalarında ebeveynlerin duyarlılık düzeyleri ve niteliklerini belirlemeye çalışmıştır. Ankara'nın merkezinde öğrenim gören 4. sınıf öğrencilerinin anne-babaları ile yürütülen bu çalışmanın bulgularına göre çocuğa örnek olmak amacıyla okuma yapan anne $(\% 14.3)$ ve babaların $(\% 10.4)$ oranları birbirine yakın ve düşüktür. Daha bilgili olmak (\%35.9) veya boş zamanları değerlendirmek (\%28.7) amacıyla pek fazla kitap okumayı tercih etmemektedir. Ebeveynlerin kitap okumadaki amaçları kendilerini geliştirmektir. Ebeveynlerin büyük bir bölümü kitap okumanın önemli olduğunu ifade etmiştir. Ebeveynler kitap okumanın önemli olduğunun farkında ancak bu alışkanlıklarını geliştirmek için gerekli olan aktiviteleri çocukları ile yapmamaktadır. Anne-babaların okuma tutumlarının düzeyine bağıı olarak çocuklarının okumaya yönelik tutumları da değişmektedir. Dolayısıyla ailenin bilinçli olması ve okuma alışkanlığının öneminin farkında olmasının çocukların okuma tutumlarını etkileyebileceği düşünülmektedir.

Araştırmanın ikinci alt problemi anne-babaların okuma tutumlarının cinsiyetlerine göre değişkenlik gösterip göstermediğini belirlemektedir. Araştırmanın bulgularına göre anne-babaların okuma tutumlarının cinsiyetlere göre yalnızca kitap okuma alışkanlığına ilişkin tutumların incelendiği 1. faktörde anlamlı bir fark gösterdiği, diğer faktörlerde ve toplam tutum puanında ise anlamlı bir farkın olmadığı belirlenmiştir. Kitap okumanın yararlarına ilişkin tutum, veli-kitap ilişkisi, çocuğu okumaya motive etmeye ilişkin tutum ve toplam tutum puanında kadınlar ile erkekler arasında anlamlı fark görülmemiştir. İncelenen literatürde okumaya ilişkin tutumlardan ziyade okuma alışkanlığının düzeylerine yönelik araştırmaların bulunduğu görülmüştür. Buna göre Nazlı'nın (2016) araştırmasına göre ebeveynlerin eşlerinin okuma alışkanlıklarını değerlendirdikleri sonuçlarda babalara göre annelerin, okuma alışkanlığı konusunda bilinçli oldukları görülmektedir. Annelerin büyük bir çoğunluğu eşlerinde okuma alışkanlığının olmadığını veya bu alışkanlık konusunda yeterli olmadıklarını belirtmiştir. Benzer şekilde Yılmaz'ın (2004), öğrencilerin okuma alışanlıkları ve kütüphane kullanım durumları konusunda anne-babalarının duyarlııklarını incelemiştir. Buna göre çocukların gözlemlerine göre ebeveynlerin büyük çoğunluğunun hiç kitap okumadıkları, bu oranın babalarda \%39.5, annelerde ise \%49.7 olduğu belirlenmiştir. Çok okuduğunu ifade eden annelerin oranı yalnızca \%2.3 ve babaların oranı \%4.7'dir. Seyrek okuduğunu ve hiç okumadığını ifade eden ebeveynlerin oranının annelerde \%85, babalarda ise \%75 olduğu tespit edilmiştir. Annelerin kitap okumaya ilişkin durumlarının babalara göre daha olumsuz olduğu belirlenmiştir. Anne-babaların okuma tutumunu belirlemese de kitap okuma alışkanlığı da tutum ile ilişkilidir. Çünkü kitap okumaya ilişkin olumlu tutuma sahip olan kişilerin okuma alışkanlıkları da yüksek olmaktadır. Bu sebeple, kitap okuma alışkanlığına ilişkin tutumların incelendiği 1.faktörde okuma tutumları daha yüksek çıkan kadınların diğer araştırmalardaki okuma alışkanlıklarının yüksek çıkması arasında paralellik olduğu söylenebilir. Güngör'ün (2009) çalışmasında öğrencilerin kitap okuma alışkanlıklarında anne-babalarıın ne derecede etkili olduğu noktasında "tamamen" derecesinde ifade ettikleri görülmüştür. Bu bulgu, anne-babaların öğrencilerin kitap okumalarında etkili olduğunu vurgulamaktadır.

Araştırmanın üçüncü alt probleminde anne-babaların okuma tutumlarının yaşlarına göre farklılaşıp farklılaşmadığı incelenmiştir. Araştırma sonuçlarına göre alt faktörlerde ve toplam tutumda anne-babaların yaşları ile okuma tutumları arasında anlamlı bir farklılığa rastlanmamıştır. Diğer bir ifade ile anne-babaların okuma tutumları, yaşlarına bağlı olarak değişkenlik göstermemektedir. Alanyazında anne-babaların yaşları ile okuma tutumları arasındaki ilişkiyi inceleyen çalışmalara rastlanmamıştır. Ancak kitap okuma alışkanlığı çocuklukta kazanılan ve yaşam boyu devam eden bir alışkanlık olduğundan yaşa göre farklılaşmaması beklenen bir sonuçtur. 
Araştırmanın dördüncü alt probleminde anne-babaların okuma tutumlarının öğrenim durumlarına göre farkılış̧ıp farklılaşmadığı belirlenmeye çalışılmıştır. Analiz sonuçları incelendiğinde anne-babaların öğrenim durumları ile okuma tutumları arasında toplam tutum ile kitap okuma alışkanlığına ilişkin tutum, kitap okumanın yararlarına ilişkin tutum ve çocuğu okumaya motive etmeye ilişkin tutumda anlamlı bir fark görülmüştür. Analiz sonuçlarına göre toplam tutumlarda öğrenim durumu okuryazar olan ile üniversite olan anne-babalar arasında öğrenim durumu üniversite olan anne-babalar lehine anlamlı bir fark görülmüştür. 1. faktörde öğrenim durumu ortaokul ile üniversite olan anne-babalar arasında öğrenim durumu üniversite olan anne-babalar lehine anlamlı fark ortaya çıkmıştır. 2. faktörde öğrenim durumu üniversite olan anne-babalar ile okuryazar olan ve ilkokul olan anne-babalar arasında öğrenim durumu üniversite olan anne-babalar lehine anlamlı bir fark olduğu belirlenmiştir. 4. faktörde öğrenim durumu okuryazar ile lise, üniversite ve lisansüstü olan annebabalar arasında öğrenim durumu lise olanlar lehine anlamlı bir fark oluştuğu ortaya çıkmıştır. Bunun yanı sıra öğrenim durumu ilkokul olanlar ile lise olanlar arasında öğrenim durumu lise olan annebabaların lehine, öğrenim durumu ilkokul olanlar ile üniversite olanlar arasında öğrenim durumu üniversite olan anne-babalar lehine anlamlı farklılık olduğu görülmektedir. Nazlı'nın (2016) çocukların okuma alışkanlığı edinmesi aşamalarında ebeveynlerin duyarlılık düzeyleri ve niteliklerini belirlemek amacıyla yürüttüğü çalışma bu sonuçlarla tutarlılık göstermektedir. Buna göre lisans mezunu, lisansüstü ve doktora mezunu anne ve babaların büyük bir kısmı ailenin okuma alışkanlığını edindirmede önemli bir etken olduğunu belirtmiştir. Okuma alışkanlığı kazanmada ailenin öneminin fark edilmesi noktasında alınan eğitimin önemli olduğu düşünülmektedir. Eğitim seviyesi arttıkça okuma alışkanlığı ve tutumun artması beklenen bir durumdur.

Literatürde anne-babaların öğrenim durumlarının çocuklarının okuma tutumlarını ne şekilde etkilediği ile ilgili yapılan araştırmalar da bulunmaktadır. Erdoğan ve Demir'in (2016) yürüttüğü çalışmada annelerin eğitim düzeyi ile okumaya ilişkin tutumları arasında anlamlı bir farklılık görülmemektedir. Ayrıca, anneleri üniversite mezunu olan öğrencilerin okumaya yönelik tutumlarının daha yüksek olduğu görülmektedir. Akkaya ve Özdemir'in (2013) ortaöğretimde öğrenim gören öğrencilerin okumaya ilişkin tutumlarının ebeveynlerinin öğrenim düzeyine ve mesleğine göre anlamlı farklılaşma gösterip göstermediğini belirlemek amacıyla yaptığı çalışmada ise öğrencilerin okumaya ilişkin tutumlarının ebeveynlerinin öğrenim düzeyine ve mesleğine göre anlamlı bir farklılık belirtmediği görülmüştür. Bu durumların araştırmanın sonuçları ile örtüşmediği görülmektedir. Bunların yanı sıra literatür incelendiğinde anne-babaların öğrenim durumlarına göre öğrencilerin okuma tutumlarında anlamlı bir farklııı̆ın görüldüğü çalışmalar da vardır. Annelerin eğitim seviyesi arttıkça kitap okuma eğilimlerinin arttığı gözlemlenmiştir. Odabaş, Odabaş ve Polat (2008) tarafından yapılan araştırmaya göre anneleri ilkokul mezunu olan öğrencilerin (\%64.5) bir yıl içinde en düşük seviyede kitap okuyan (1-5 kitap) öğrenciler olduğu belirlenmiştir. Bu oranın eğitim seviyesi daha yüksek annelerde azaldığı, örneğin annelerinin öğrenim durumu üniversite olan öğrencilerde yoğunluğun orta seviyeli okur tipinde olduğu anlaşılmıştır. Aynı durum, babaların öğrenim durumunun çocukların okuma alışkanlığına yansımasında da görülmektedir. Babaları ilkokul ve ortaöğretim mezunu olan öğrencilerin genellikle okumaya yönelik tutumunun düşük olduğu grupta olduğu görülmüştür. Bu veriye göre öğrenim durumu ortaöğretim olan babaların çocuklarının \%4.6'sı son bir senede hiç kitap okumadığını ifade etmektedir. Ayrıca bir senede 1-5 kitap okuyanların oranı \%49.7, 6-11 kitap okuyanların oranı \%38.1 ve 12 kitaptan çok okuyanların oranı ise \%7.6 olarak belirtilmiştir. Dolayısıyla ebeveynlerin öğrenim durumu yükseldikçe senede 12 ve daha fazla kitap okuyan öğrencilerin yüzdesinin \%10'dan \%26.7'ye çıkması okuma alışkanlığını edinme noktasında babaların öğrenim durumunun ne kadar önemli olduğunu göstermektedir. Güngör'ün (2009) araştırmasına göre öğrencilerin kitap okuma alışkanlık düzeylerini ebeveynlerin eğitim durumlarının etkilediği görülmüştür. Bunun yanı sıra Güngör'ün (2009) çalışması incelendiğinde, anne-babanın eğitim seviyesi arttıkça boş vakitlerinde daha çok okuma yaptığı, ebeveynlerin çocuklarına daha sık kitap aldığı ve buna bağlı olarak çocukların okuduğu kitap sayısının arttığı belirlenmiştir.

Araştırmanın beşinci alt probleminde anne-babaların okuma tutumlarının mesleklerine göre farklılaşıp farklılaşmadığı belirlenmeye çalışılmıştır. Bulgulara göre anne-babaların okuma tutumları, mesleklerine bağlı olarak değişkenlik göstermemektedir. Araştırma, Akkaya ve Özdemir'in (2013) 
ortaöğretimde öğrenim gören öğrencilerin okumaya ilişkin tutumlarının ebeveynlerinin öğrenim düzeyine ve mesleğine göre anlamlı farklılaşma gösterip göstermediğini belirlemek amacıyla yaptığı araştırma ile örtüşmemektedir. Bu çalışmaya dahil olan ortaöğretim öğrencilerinin okumaya ilişkin tutumlarının, ebeveynlerinin mesleğine göre anlamlı bir farklılık belirtmediği görülmüştür. Fakat burada bağımlı değişkenin öğrencilerin okuma tutumu olduğu görülmektedir. İlgili alan yazında doğrudan anne-babaların mesleklerine göre okuma tutumlarını belirleyen araştırmalara rastlanmamıştır.

Araştırmanın altıncı alt problemi anne-babaların okuma tutumlarının aylık gelirlerine göre farklılaşıp farklılaşmadığını belirlemektedir. Analiz sonuçları incelendiğinde toplam tutumda ve kitap okumanın yararlarına ilişkin tutumda anne-babaların aylık gelirleri ile okuma tutumları arasında anlamlı bir farklılık olduğu belirlenmiştir. Toplam tutumda aylık geliri 4000 ve üzeri olanlar ile 1-1500 aralığında olanlar, 2000-2500 aralı̆ıında olanlar ve 3000-3500 aralığında olanlar arasında anlamlı farklılık görülmüştür. Bu anlamlı farkın aylık geliri 4000 ve üzeri olanlar lehine olduğu belirlenmiştir. 2. faktörde çıkan anlamlı fark ise aylık geliri 4000 ve üzeri olanlar ile 1-1500 aralığında olanlar ve 2001-2500 aralığında olanlar arasında aylık geliri 4000 ve üzeri olanlar lehine, aylık geliri 2001-2500 aralığında olanlar ile 3501-4000 aralı̆ında olanlar arasında 3501-4000 aralığında olanlar lehine anlamlı farklılık olduğu belirlenmiştir. Ayrıca aylık geliri 2501-3000 aralı̆ıında olanlar ile 1-1500 aralığında olanlar ve 2001-2500 aralığında olanlar arasında 2501-3000 aralığında olanlar lehine anlamlı farklılık saptanmıştır.

Literatürde okumaya ilişkin tutumla aylık gelir arasında anlamlı bir ilişki olduğunu belirten araştırmalar olduğu gibi, anlamlı ilişkinin olmadığını belirten araştırmalara da bulunmaktadır. Balcı (2009), Baş (2012), Başaran ve Ateş (2009), Güngör (2009), Keleş (2006) ve Topçu (2007) yürüttükleri çalışmalarda aylık gelir ile okuma tutumu arasında ilişki olduğunu ifade etmektedirler. Akkaya ve Özdemir (2013) ortaöğretim öğrencilerinin okumaya ilişkin tutumlarının bazı değişkenlere göre farklılık gösterip göstermediğini belirlemek amacıyla bir araştırma yapmıştır. Bu araştırmaya katılan öğrencilerin okumaya ilişkin tutumları ile ebeveynlerinin ekonomik düzeyi arasında düşük bir ilişki saptanmıştır. Baş'ın (2012) yürüttüğü çalışmada da lise öğrencilerinin okuma tutumlarının ailenin finansal gelir seviyesi değişkenine bağlı olarak farklıık gösterdiği bulunmuştur. Finansal gelir seviyeleri 501-1000, 1001-1500, 1501-2000 ve 2001 ve üstü olarak belirlenmiştir. Araştırmada 1000 TL ve altında gelir seviyesine sahip olan öğrencilerin dezavantajlı olduğu ortaya çıkmıştır. Bu çalışmalara paralel olarak ilköğretim 5. sınıf öğrencilerinin okuma tutumlarını ve bu tutumların çeşitli değişkenlerden ne derecede etkilendiğini saptamak için yapılan araştırmada il merkezinde yaşayan öğrencilerin üst sosyoekonomik seviyedeki ailelerin çocukları olduğu belirtilmiştir. İ merkezinde yaşayan öğrencilerin okumaya yönelik tutumlarının, ilçe ve kasabalarda yaşayan öğrencilerin tutumlarına göre daha olumlu olduğu belirlenmiştir. Dolayısıyla sosyoekonomik düzeyi yüksek olan ailelerin çocuklarının okumaya ilişkin tutumlarının daha yüksek olduğu söylenebilir (Başaran ve Ateş, 2009). Bunların yanı sıra alanyazında aylık gelir ile okuma tutumu arasında ilişki olmadığını belirleyen araştırmalar da vardır (Acıyan, 2008; Can vd., 2010; Çetinkaya, 2004; Gönen vd., 2004; Kurulgan ve Çekerol, 2008; Odabaş vd., 2008; Sevmez, 2009; Stokmans, 1999). İlkokul dördüncü sınıf öğrencilerinin okumaya ilişkin tutumlarının bazı demografik değişkenler aracılığıyla incelenmesi amacıyla yapılan araştırmaya katılan öğrencilerin algıladıkları aile aylık geliri ile okumaya ilişkin tutumları arasında anlamlı bir farklılık bulunmadığı belirlenmiştir (Erdoğan ve Demir, 2016). Balcı, Uyar ve Büyükikiz'in (2012) yaptığı çalışmada, ilköğretim 6. sınıf öğrencilerinin okuma alışkanlıkları, kütüphane kullanma sıklıkları ve okumaya ilişkin tutumlarının incelenmesi amaçlanmıştır. İlköğretim 6. sınıf öğrencilerinin sosyoekonomik çevre değişkeni ile okumaya ilişkin tutumları arasında anlamlı bir farklıık olmadığı görülmüştür. Farklı sosyoekonomik çevrelerde bulunan öğrencilerin tutum ölçeğinden aldıkları puanların ortalamaları incelendiğinde ise grupların birbirine yakın değerlere sahip olduğu görülmüştür.

Araştırmanın yedinci alt problemi anne-babaların okuma tutumlarının çocuk sayılarına göre değişkenlik gösterip göstermediğini belirlemektedir. Analiz sonuçları incelendiğinde anne-babaların çocuk sayıları ile okuma tutumları arasında anlamlı bir farklılığa rastlanmamıştır. Diğer bir ifadeyle anne-babaların okuma tutumları, çocuk sayısına bağlı olarak değişkenlik göstermemektedir. Anne- 
babanın okuma tutumu ile çocuk sayısını ilişkilendiren bir veri bulunamadığından bu karşılaştırma yapılamamıştır.

Araştıranın sekizinci alt problemi anne-babaların okuma tutumlarının kitap okuma sıklıklarına göre farklılaşıp farklılaşmadığını incelemektedir. Analiz sonuçları incelendiğinde toplam tutumda ve tüm alt faktörlerde anne-babaların kitap okuma sıklıkları ile okuma tutumları arasında anlamlı farklılık görülmüştür. Diğer bir deyişle ile anne-babaların okuma tutumları, kitap okuma sıklıklarına bağlı olarak değişkenlik göstermektedir. Analiz sonuçlarına göre toplam tutumda hiç okumam diyenlerle 0-5 okurum, 6-10 okurum, 11-15 okurum ve 15 ve üzeri okurum diyenler arasında 0-5 okurum, 6-10 okurum, 11-15 okurum ve 15 ve üzeri okurum diyenler lehine anlamlı bir farklılık olduğu ortaya çıkmıştır. Ayrıca toplam tutumda 15 ve üzeri okurum diyenler ile hiç okumam, 0-5 okurum, 6-10 okurum diyenler arasında 15 ve üzeri okurum diyenler lehine anlamlı farklılık gözlenmiştir.

Kitap okuma alışkanlığına ilişkin tutumda hiç okumam diyenlerle diğer seçenekler arasında diğer seçenekler lehine anlamlı farklılık görülmüştür. 15 ve üzeri okurum diyenlerle hiç okumam, 0-5 okurum, 6-10 okurum diyenler arasında 15 ve üzeri okurum diyenler lehine anlamlı farklılık ortaya çıkmıştır. Kitap okumanın yararlarına ilişkin tutumda hiç okumam diyenler ile 0-5 okurum diyenler arasında 0-5 okurum diyenler lehine, hiç okumam diyenler ile 11-15 okurum diyenler arasında 11-15 okurum diyenler lehine, hiç okumam diyenlerle 15 ve üzeri okurum diyenler arasında 15 ve üzeri okurum diyenler lehine, 15 ve üzeri okurum diyenler ile 0-5 okurum, 6-10 okurum diyenler arasında 15 ve üzeri okurum diyenler lehine anlamlı bir farklılık olduğu görülmüştür. Veli-kitap ilişkisi ile ilgili tutumda hiç okumam diyenler ile 11-15 okurum diyenler arasında 11-15 okurum diyenler lehine, hiç okumam diyenler ile 15 ve üzeri okurum diyenler arasında 15 ve üzeri okurum diyenler lehine, 15 ve üzeri okurum diyenler ile 6-10 okurum, 0-5 okurum diyenler arasında 15 ve üzeri okurum diyenler lehine anlamlı farklılık olduğu ortaya çıkmıştır. Çocuğu kitap okumaya motive etmeye ilişkin tutumda ise 15 ve üzeri okurum diyenler ile hiç okumam, 0-5 okurum, 6-10 okurum diyenler arasında 15 ve üzeri okurum diyenler lehine anlamlı farklılık görülmüştür. Kitap okumaya ilişkin tutum yüksek olan kişinin kitap okuma sıklığı da yüksek olmaktadır. Çünkü kişiler olumlu tutuma sahip oldukları davranışları sergileme eğilimindedirler. Bu durumda 15 ve üzeri okurum diyen anne-babaların okuma tutumlarının yüksek olması beklenen bir sonuçtur.

Araştırmanın dokuzuncu alt problemi ilkokul 4. Sınıf öğrencilerinin Türkçe dersi akademik başarılarının ne düzeyde olduğunu belirlemektedir. Araştırmanın sonucuna göre öğrencilerin Türkçe dersi akademik başarılarının yüksek düzeyde olduğu görülmektedir. Araştırmanın onuncu alt problemi ilkokul 4. Sınıf öğrencilerinin Türkçe dersi akademik başarılarının kitaplıklarının olup olmamasına göre değişkenlik gösterip göstermediğini belirlemektir. Bulgular incelendiğinde, çocukların kitaplıklarının varlığı ile Türkçe dersi akademik başarıları arasında anlamlı bir farklılık olmadığı görülmektedir. Diğer bir deyişle çocukların Türkçe dersi akademik başarıları kitaplıklarının varlığına göre değişkenlik göstermemektedir. Literatür incelendiğinde bu sonuçlarla tutarlılık gösteren çalışmalara rastlanmamıştır. Güngör'ün (2009) yaptığı çalışmada öğrencilerin büyük bir kısmının kitaplığa sahip olduğu belirlenmiştir. Yine Tosunoğlu'nun (2002) 4 ve 5. sınıf öğrencilerinden oluşan 350 öğrenci ile yürüttüğü araştırmanın sonuçları incelendiğinde öğrencilerin \%77.5'inin evinde kitaplık olduğu saptanmıştır. Öztürk ve Aksoy (2016) ise ilkokul öğrencilerinin okumaya yönelik tutumlarını ebeveynlerinin görüşleri aracılığıyla tespit etmeye çalışmıştır. Velilerin evde çocuklarına ait kitaplık olup olmadığına yönelik ifadelerine bakıldı̆ında, neredeyse tamamının çocuklarının kendi kitaplıklarııın veya kendilerine ayrılmış bir rafın bulunduğunu ifade ettiği görülmüştür. Bunun yanı sıra ebeveynlerin \%35.2'si çocuklarının okuma alışkanlığına sahip olmadığını ifade etmesine karşın ebeveynlerin büyük çoğunluğunun okumaya önem vererek çocuklarının kendi kitaplıklarını oluşturmasını sağladıkları belirlenmiştir. İnan (2005) yürüttüğü çalışmada okuma alışkanlığının edinilmesinde evde bir kitaplığın olmasının ve bu kitaplıkta da çocukların kendilerine ait kitapların bulunmasının oldukça etkili olduğunu belirtmektedir. Ünal ve Yiğit'in (2014) çalışmasında ebeveynler kitaplık oluşturmanın yararlarını kitaplara yönelik olumlu tutumu artırması ve bilgiye erişimin kolay olmasını sağlaması biçiminde ifade etmektedirler. Yapılan analizler sonucunda öğrencilerin akademik başarılarının kitaplıklarının olup olmamasına göre değişkenlik göstermemesi, öğrencilerin okul kütüphanesinden faydalanması ya da 
arkadaşlarıyla kitap değişiminde bulunmasından dolayı kaynaklandığı, bu sebeple evde kitaplık intiyacının olmadığı şeklinde yorumlanabilir.

Araştırmanın on birinci alt problemi ilkokul 4. Sınıf öğrencilerinin Türkçe dersi akademik başarılarının anne-babalarının kitap okuma sıklıklarına göre değişkenlik gösterip göstermediğini belirlemektir. Analiz sonuçları incelendiğinde anne-babaların kitap okuma sıklıkları ile çocukların Türkçe dersi akademik başarıları arasında anlamlı bir fark görülmemiştir. Başka bir deyişle çocukların Türkçe dersi akademik başarıları, anne-babalarının kitap okuma sıklıklarına bağlı olarak değişkenlik göstermemektedir. Alan yazında araştırma sonuçlarıyla örtüşmeyen çalışmalara da rastlanmıştır. Güngör'ün (2009) çalışmasına göre akademik olarak başarılı olan öğrencilerin okul öncesi dönemde ebeveynlerinin diğer ebeveynlere göre daha fazla kitap okuduğu (\%67.8), evlerinde diğer ebeveynlere oranla daha fazla kitaplığa sahip oldukları (\%85), akademik başarı seviyesi arttıkça okunan kitap sayısında da artış görüldüğü (\%62.9) belirlenmiştir. Evde aile bireyleri ile ortak okuma etkinliği oluşturmanın düzeni ve disiplini sağlayacağı saptanmıştır. Okumayla alakalı ilk etkinliklerin aile ortamında sağlanmasının gerekliliği, sınıfta okuma etkinlikleri planlayarak öğrencilerin düzenli bir şekilde okulun haricinde de günlük olarak okumaya karşı motive edilmesi gerektiği, okulun haricinde okuma etkinliği yapılmasının ders başarısını arttırdığı Özer ve Doğan'ın (2013) araştırmasında ifade edilmektedir. Durualp, Çiçekoğlu ve Durualp'in (2013) yaptığı araştırmasına göre ebeveynleri kitap okuyan çocuklar ölçeğin toplamından yüksek puan almıştır. Bu sonuç, ebeveynlerin kitap okumasının çocukların okuma tutumunda önemli rol oynadığını belirtmektedir.

Araştırmanın on ikinci alt problemi ilkokul 4. Sınıf öğrencilerinin Türkçe dersi akademik başarıları ile anne-babalarının okuma tutumları arasında bir ilişki olup olmadığını belirlemektir. Bulgulara göre ilkokul 4. Sınıf öğrencilerinin Türkçe dersi akademik başarıları ile anne babalarının okuma tutumları arasında düşük düzeyde anlamlı ve pozitif bir ilişkiye rastlanmıştır. Zorbaz ve Habeş'in (2015) araştırmasında da Türkçe dersi karne notu 3 olanların 1 olanlara, karne notu 4 ve 5 olan öğrencilerin 3 ve daha düşük olanlara göre Türkçe dersine ilişkin tutumlarının daha olumlu olduğu saptanmıştır. Bunun yanı sıra Türkçe dersi karne notunun Türkçe dersine ilişkin tutum üzerinde orta düzeyde etkili olduğu sonucuna ulaşılmıştır.

Bu sonuçlar doğrultusunda aşă̆ıdaki öneriler geliştirilmiştir:

- Aileler çocuklarının bulunduğu her ortamda kitap okuyarak onlara rol model olmalı, kitap okumanın düzenli bir alışkanlık olduğunu benimsetmeye çalışmalıdırlar.

- Öğretmenler tarafından ailelere çocuklarının kitap okuma alışkanlığını evde nasıl destekleyecekleri ile ilgili bilgilendirme çalışmaları yapılmalıdır.

- Aileler çocuklarına okuma becerisi kazandırmak adına okul öncesi dönemden başlayarak tüm eğitim hayatı boyunca çocuğun ilgisine, isteğine, yaşına ve seviyesine uygun okuma materyallerini sunmalıdırlar.

- Bu araştırma ilkokul 4. Sınıf öğrencilerinin anne-babalarının okuma tutumları ile Türkçe dersi akademik başarısı arasında bir ilişki olup olmadığını belirlemek amacıyla yapılmıştır. İlköğretimin ve ortaöğretimin farklı sınıf seviyelerine yönelik çalışmalar yapılarak okuma alışkanlığının sınıf seviyeleri açısından incelemesi değerlendirilebilir.

- Bu araştırma ebeveynlerin okuma tutumunun öğrencilerin akademik başarısı üzerine etkilerini araştırmak amacıyla yapılmıştır. Öğrencilerin akademik başarısını etkileyen diğer değişkenlerin incelendiği çalışmaların da alana katkı sağlayacağı düşünülmektedir.

\section{Kaynaklar}

Acıyan, A. A. (2008). Ortaöğretim öğrencilerinin okuma alışkanlıkları ve akademik başarı düzeyleri arasındaki ilişki (Yayınlanmamış yüksek lisans tezi). Yeditepe Üniversitesi, Sosyal Bilimler Enstitüsü, İstanbul.

Akkaya, N. ve Özdemir, S. (2013). Ortaöğretim öğrencilerinin okumaya yönelik tutumlarının incelenmesi (İzmir-Buca örneği). Bartın Üniversitesi Eğitim Fakültesi Dergisi, 2(1), 75 - 96.

Aksaçlıoğlu A. ve Yılmaz B. (2007). Öğrencilerin televizyon izlemeleri ve bilgisayar kullanmalarının okuma alışkanlıkları üzerine etkisi. Türk Kütüphaneciliği, 21(1), 3-28. 
Akyol, H. (2008). Türkçe öğretimi. Ankara: Kök Yayınları.

Akyol, H. ve Şahin, A. (2019). Dilbilgisi ve İmla Öğretimi. H. Akyol ve A. Şahin (Ed.), Türkçe Öğretimi (1. Baskı) (ss. 213-241). Ankara: Pegem Akademi.

Alamdar, S. (2015). Akademik başarıyı etkileyen faktörlerin etkili okul kavramı bağlamında incelenmesi. Ankara Üniversitesi, Eğitim Bilimleri Enstitüsü. Yüksek Lisans Tezi. Ankara.

Arıcl, A.F. ve Taşkın, Y. (2109) Relationship Between Readıng Skills And Other Language Skills. International Journal of Field Education. 5(2), 185-194.

Balcı, A. (2009). İlköğretim 8. sınıf öğrencilerinin kitap okuma alışkanlığına yönelik tutumları. Mustafa Kemal Üniversitesi Sosyal Bilimler Enstitüsü Dergisi, 6(11), 265-300).

Balcı, A., Uyar,Y. ve Büyükikiz, K. K.(2012). Illköğretim 6. sınıf öğrencilerinin okuma alışkanlıkları, kütüphane kullanma sıklıkları ve okumaya yönelik tutumlarının incelenmesi. Turkish StudiesInternational Periodical For The Languages, Literature and History of Turkish or Turkic, 7(4), 965-985.

Baş, G. (2012). Reading attitudes of high school students: an analysis from different variables. International Journal on New Trends in Education and Their Implications, 3 (2), 4758.

Başaran, M. ve Ateş, S. (2009). İlköğretim beşinci sınıf öğrencilerinin okumaya ilişkin tutumlarının incelenmesi. Gazi Üniversitesi Eğitim Fakültesi Dergisi, 29(1), 73-92.

Çelenk, S. (2006). Etkinlik temelli ilkokuma ve yazma öğretimi. İstanbul: Morpa Kültür Yayınları.

Çetinkaya, Ç. S. (2004). Afyon merkezindeki ilköğretim 8. sınıf öğrencilerinin okuma alışkanlığı (Yayımlanmamış yüksek lisans tezi). Afyon Kocatepe Üniversitesi, Sosyal Bilimler Enstitüsü, Afyon.

Devrimci, H. (1993). İlkokul 5. sınıf çocuklarında okuma alışkanlığının incelenmesi. Hacettepe Üniversitesi, Sağlık Bilimleri Enstitüsü. Bilim Uzmanlığı Tezi. Ankara.

Dursun, H. (2018), ilkokul 4. sınıf öğrencilerinin okuma kaygıları ile Türkçe dersine yönelik tutumları arasındaki ilişki. Niğde Ömer Halisdemir Üniversitesi, Eğitim Bilimleri Enstitüsü. Yüksek Lisans Tezi. Niğde.

Durualp, E., Çiçekoğlu, P. ve Durualp, E. (2013). Sekizinci sınıf öğrencilerinin kitap okumaya yönelik tutumlarının internet ve kitap okuma alışkanlıkları açısından incelenmesi. Ulus/ararası Türkçe Edebiyat Kültür Eğitim Dergisi, 2(1), 115-132.

Elbir, B. ve Bağcl, C. (2013). Birinci ve ikinci kademe okuma eğitimi üzerine yapılan lisansüstü çalışmaların değerlendirilmesi. Adıyaman Üniversitesi Sosyal Bilimler Enstitüsü Dergisi Türkçenin Eğitimi Öğretimi Özel Sayısı, 11, 229-247.

Ercik, S. (2016). Aile, okul ve özel dershanelerin seviye belirleme sınavına katılan öğrencilerin akademik başarıları üzerindeki etkileri. Yüzüncü Yıl Üniversitesi, Sosyal Bilimler Enstitüsü. Yüksek Lisans Tezi. Van.

Erdoğan Gür, D, Demir, Y. E. (2016). İlkokul 4. sınıf öğrencilerinin okumaya yönelik tutumlarının farklı değişkenler açısından incelenmesi. Sakarya Üniversitesi Eğitim Fakültesi Dergisi, 32, 85-96.

Gömleksiz, M. N. (2004). Geleceğin öğretmenlerinin kitap okumaya ilişkin görüşlerinin değerlendirilmesi (Fırat Üniversitesi Eğitim Fakültesi örneği). Yüzüncü Yıl Üniversitesi Eğitim Fakültesi Dergisi, 1(1), 1- 21.

Gönen, M., Öncü, E. Ç. ve Işıtan, S. (2004). Ilköğretim 5., 6. ve 7. sınıf öğrencilerinin okuma alışkanlıklarının incelenmesi. Milli Eğitim Dergisi, 32 (164), 7-34.

Göngör, E. (2009). Illköğretim 5. sınıf öğrencilerinin kitap okuma alışkanlığı ile Türkçe dersi akademik başarıları arasındaki ilişkinin incelenmesi (Yayımlanmamış yüksek lisans tezi). Çukurova Üniversitesi, Sosyal Bilimler Enstitüsü, Ankara.

Güneş, F. (2017). Okuma ve Sınırsız Öğrenme. Sınırsız Eğitim ve Araştırma Dergisi, 2 (1), 1-20.

İnan, D. D. (2005). ilköğretim I. kademe öğrencilerinin okuma alışkanlıklarının incelenmesi (Yayımlanmamış yüksek lisans tezi). Marmara Üniversitesi, Eğitim Bilimleri Enstitüsü. İstanbul.

Keleş, Ö. (2006). IIlköğretim 4. ve 5. sınıf öğrencilerinde kitap okuma alışkanlığının incelenmesi (Yayımlanmamış yüksek lisans tezi). Gazi Üniversitesi, Eğitim Bilimleri Enstitüsü, Ankara.

Kurnaz, H. ve Yıldız, N. (2015). Ortaokul öğrencilerinin okuma motivasyonlarının çeşitli değişkenlere göre değerlendirilmesi. Türkiye Sosyal Araştırmalar Dergisi, 19(3), 53-70. 
ilkokul 4. Sınıf Öğrencilerinin Anne-Babalarının Okuma Tutumları ile Türkçe Dersi Akademik Başarısı Arasındaki ilişki

Kurulgan, M. ve Çekerol, S. (2008). Öğrencilerin okuma ve kütüphane kullanma alışkanlıkları üzerine bir araştırma. Anadolu Üniversitesi Sosyal Bilimler Dergisi, 8(2), 237-258.

M.E.B. (2007). Öğrencilerin okuma düzeyleri. Ankara: Milli Eğitim Bakanlığı.

Odabaş, H., Odabaş, Y., Z. ve Polat, C. (2008). Üniversite öğrencilerinin okuma alışkanlığı: Ankara Üniversitesi örneği. Bilgi Dünyası, 9(2), 431-465.

Özbay, M. (2005). Bir dil becerisi olarak dinleme eğitimi. Ankara: Akçağ Yayınları.

Özbay, M. (2006). Okuma eğitiminde çevre faktörü. Eurasian Journal of Educational Research, 24, 161170.

Özer Özkan, Y. ve Doğan, B. (2013). İlköğretim 8. sınıf öğrencilerinin okuma becerisinin kestirilmesinde etkili olan değişkenlerin belirlenmesi. International Journal of Social Science, 6(4), 667-680.

Öztürk, S. D. ve Aksoy, E. (2016). Illköğretim öğrencilerinin okuma alışkanlığına ilişkin veli görüşleri. Abant İzzet Baysal Üniversitesi Eğitim Fakültesi Dergisi, 16(2), 562-591.

Sevmez, H. (2009). Türkçe öğretmen adaylarının okuma alışkanlığı ve kütüphane kullanımı üzerine bir inceleme. Selçuk Üniversitesi, Sosyal Bilimler Enstitüsü. Yüksek Lisans Tezi. Konya.

Stokmans, M. J. W. (1999). Reading attitude and its effect on leisure time reading. Poetics. 26, 245261.

Topçu, Y. E. (2007). İlköğretim 6,7 ve 8. Sınıf Öğrencilerinin Okuma Alışkanlıkları. Milli Eğitim Dergisi, 176, 36-57.

Tosunoğlu, M. (2002). Türkçe öğretiminde okuma alışkanlığı ve çocukların okuma eğilimleri. Türk Dili, 609, 547-563.

Alpoğuz, D,U. (2014). Algılanan ana-baba tutumlarının ilköğretim öğrencilerinin okumaya yönelik tutumlarına ve Türkçe dersi akademik başarılarına etkisi. Kırşehir Ahi Evran Üniversitesi, Sosyal Bilimler Enstitüsü. Yüksek Lisans Tezi. Kırşehir.

Ünal, F. T. ve Yiğit, A. (2014). Çocuklarda okuma kültürünün oluşmasında ailenin etkisi. International Journal of Language Academy, 2(4), 308-322.

Yıldız, B. (2016). illkokul öğrencilerinin akademik başarılarının arttırılmasında öğretmen, okul yönetimi ve öğrenci veli görüşlerinin incelenmesi. Mersin Üniversitesi, Eğitim Bilimleri Enstitüsü. Yüksek Lisans Tezi. Mersin.

Yılmaz, B. (2002). Ankara'daki ilköğretim öğretmenlerinin okuma ve halk kütüphanesi kullanma alışkanlıkları üzerine bir araştırma. Türk Kütüphaneciliği, 16 (4), 441-460.

Yılmaz, B. (2004). Öğrencilerin okuma ve kütüphane kullanma alışkanlıklarında ebeveynlerin duyarlııı̆ı. Bilgi Dünyası, 5(2), 115-136.

Zorbaz, K.Z. ve Kayatürk, N. (2015). Ortaokul öğrencilerinin yazmaya yönelik tutumlarının çeşitli değişkenlere göre incelenmesi. Eğitimde Kuram ve Uygulama, 11(4), 1415- 1435.

\section{Extended Abstract}

\section{Introduction}

Reading is a holistic process that includes comprehending, interpreting, reasoning, and concluding by perceiving written messages through sense organs. In this sense, reading is a collective activity of the sense organs (Odabaş, Odabaş \& Polat, 2008, p:433). According to Aksaçlıoğlu and Yılmaz $(2007, p: 4)$, the most effective and the oldest way of learning is reading; it is a creative, mental, and individual process. It is a fact that reading in general underlies activities in all classes because it is a means of learning and is an important tool for transferring the knowledge to a person's memory. A student who cannot ably perform reading and comprehension should not be expected to be successful academically (Çelenk, 2005, p: 142). Students who fail to develop a reading habit during elementary education may fail in the following processes (Akyol, 2009, p: 2).

There are many factors affecting the reading habit. The factors affecting the acquisition and development of this habit are social environment, family, teachers, and school (Özbay, 2006; Yılmaz 2004). Furthermore, being physically and mentally capable, students should receive the relevant education to be able to read. Reading education starts in the family. Children's readiness required for reading education occurs by providing them with a setting to read (Elbir\&Bağcl, 2013). Attitudes of 
children who have seen their parents read books should be different from those of the ones whose parents do not read regularly (Alpoğuz, 2014).

Considering that children take their families as role models, conditions affecting their academic achievement have been examined in many studies. In most studies (Alamdar, 2015; Ercik, 2016; Alpoğuz, 2014; Yıldız, 2016) the attitudes and behaviors of families were reported to affect students' academic achievements. In this context, it was considered that there was a relationship between students' academic achievements and their parents' reading attitudes. The literature offers many studies examining the relationship between students' reading attitudes and their academic achievements in Turkish course (Acıyan, 2008; Dursun, 2018; Güngör, 2009).

\section{Method}

This research paper was designed as correlational survey model, a descriptive research model. correlational survey model aims to determine whether there is a difference between two or more variables and levels of the difference if any, (Karasar, 2016, p: 114). The universe of the research consists of the $4^{\text {th }}$ grade students and their parents in Çanakkale. The sample was created by simple random sampling. 203 parents, who volunteered to participate, were included in the study. In this study, "Attitude Scale for Reading" "Personal Information Form" were used to determine the participating parents' reading attitudes and their demographic information, respectively. Both tools were developed by the researchers.

\section{Results and Discussion}

Findings showed that the parents' attitudes toward the habit of reading is high, the benefits of reading books are high, parent-book relationship is moderate, and their motivating children to read occurred is high level. The total attitude score was found to be high. Öztürk \& Yiğit (2016) report that the level of elementary school students' reading habit is in congruence with their parents' views about reading books. Although most of them were found to enjoy reading books, more than half were observed to have developed a reading habit, while the others were not.

The findings revealed that the parents' reading attitudes showed a significant difference in Factor 1, in which only the attitudes toward the habit of reading were examined, but no significant difference in the other factors and in the total attitude score. No significant by-gender difference was observed in the attitudes regarding the benefits of reading books, parent-book relationship, attitude toward motivating children to read, and in total attitude score. The review of the literature revealed some studies on levels of reading habits rather than attitudes toward it. The results of the analyses here in yielded a significant difference between the educational attitudes of the parents and their reading attitudes, the attitude toward the reading habit, toward the benefits of reading a book, and toward motivating children to read. Additionally, a significant difference was observed between the literate parents with an elementary school degree and the parents with a university degree in favor of the latter.

According to the findings, the parents' reading attitudes did not vary depending on their professions. The present research does not substantiate the results of the research by Akkaya \& Özdemir (2013), conducted to determine whether the attitudes of secondary school students differed significantly according to the education levels and professions of their parents. It was observed that the attitudes of secondary school students toward reading did not differ significantly by their parents' professions. However, the dependent variable in Akkaya \& Özdemir (2013) was the reading attitude of the students. The literature offers no study attempting to evaluate parents' reading attitudes according to their professions. The results of the present study indicated a significant difference between the parents' monthly income and their reading attitudes in the domain of total attitude and the attitude regarding the benefits of reading books. Literature offers studies stating that there is a significant relationship between reading attitude and monthly income but also studies reporting no significant relationship between these two parameters. The analyses produced no significant difference between the number of children and parents' reading attitudes. There was a significant difference between parents' reading frequency and reading attitudes in the domain of total attitude and in all the other 
sub-domains. According to the results of the study, the academic achievement of the students in Turkish course was high. It was concluded from the findings that there was no significant difference between the students' personal home library and their academic achievement in the Turkish course. The analyses indicated that the students' academic achievements did not vary according to whether they had a library at home or not because they were found to benefit from the school library or exchange books with their friends; therefore, they needed no library at home.

The analyses yielded no significant difference between the parents' reading frequencies and the students' academic achievement in Turkish course. Studies that do not correspond to the results of the present research also exist in the literature. According to the findings, a weak significant positive relationship was found between the academic achievement of the $4^{\text {th }}$ grade students and their parents' reading attitudes. In the study by Zorbaz \& Habeş (2015), it was found out that students with a grade score of 3 in Turkish class on their report cards had a more positive attitude toward the Turkish course than those with a grade score of 1 . Moreover, the students with a grade score of 4 or 5 were observed to exhibit a more positive attitude than the ones with 3 or less. In addition, it was concluded that the grade scores in Turkish class were moderately effective in the attitudes toward Turkish course. 